\title{
UNDERWATER ARCHAEOLOGY SURVEY OF 16628 MARKET STREET DREDGING HARRIS COUNTY, TEXAS
}

\author{
Prepared for: \\ 16628 Market Street, LLC \\ 16628 Market Street \\ Channelview, Texas 77530
}

Prepared by:

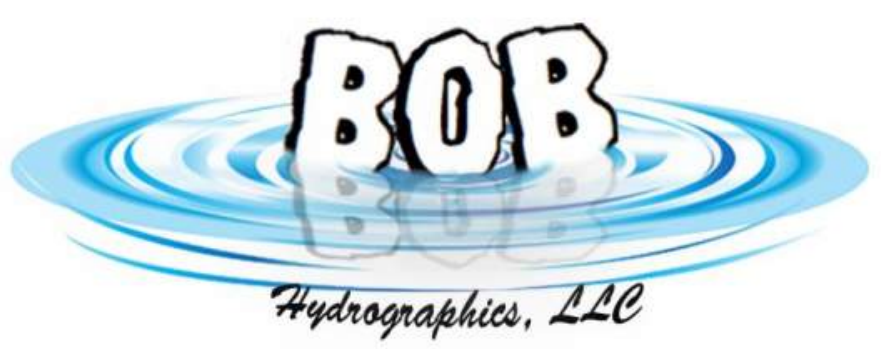

BOB Hydrographics, LLC

1315 Fall Creek Loop

Cedar Park, Texas 78613

Principal Investigator:

Robert Gearhart

July 2019 
BOB Project 2019-03

\title{
UNDERWATER ARCHAEOLOGY SURVEY \\ OF 16628 MARKET STREET DREDGING HARRIS COUNTY, TEXAS
}

Texas Antiquities Permit No. 8878

\author{
Prepared for: \\ 16628 Market Street, LLC \\ 16628 Market Street \\ Channelview, Texas 77530 \\ Prepared by: \\ BOB Hydrographics, LLC \\ 1315 Fall Creek Loop \\ Cedar Park, Texas 78613
}

Principal Investigator:

Robert Gearhart

Author:

Robert Gearhart

July 2019 


\section{Table of Contents}

Page

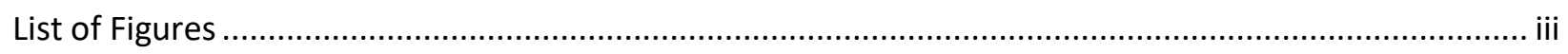

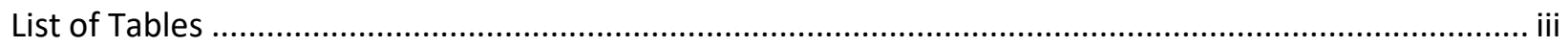

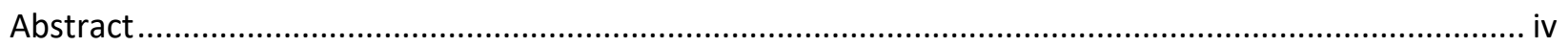

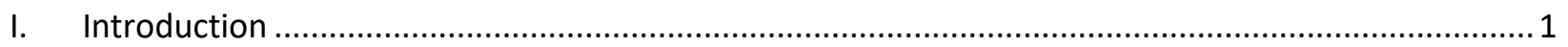

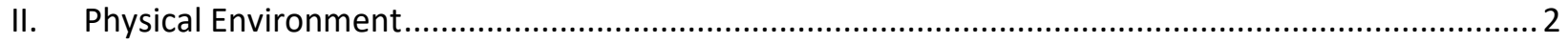

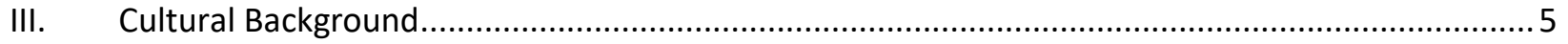

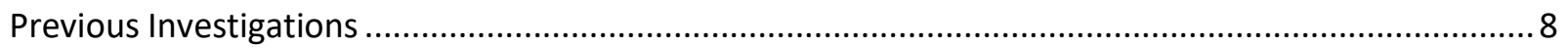

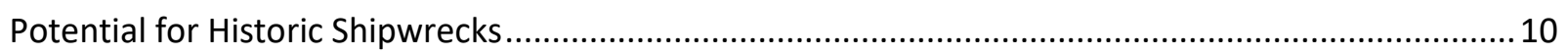

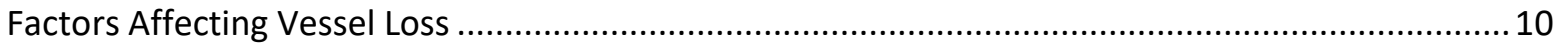

Factors Affecting Vessel Preservation....................................................................................... 12

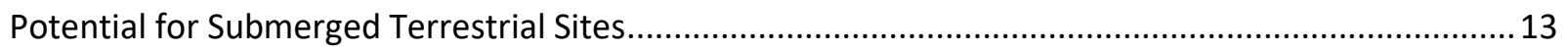

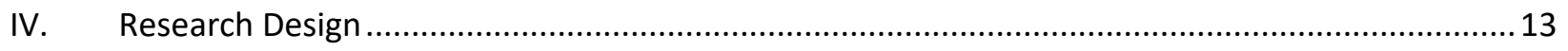

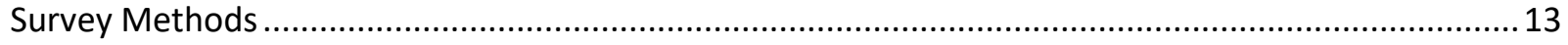

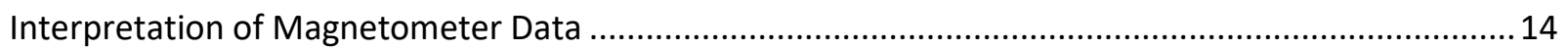

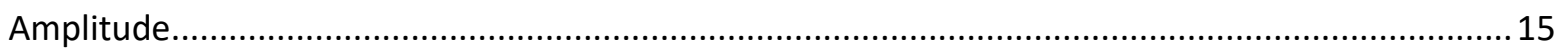

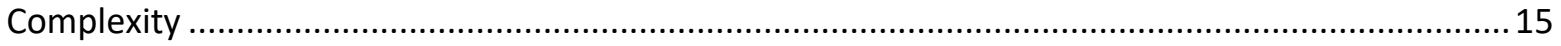

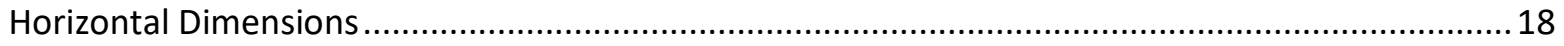

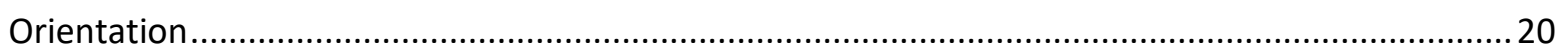

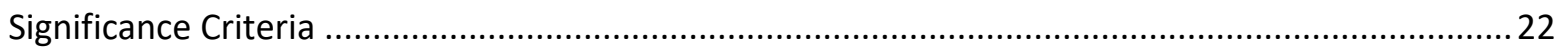

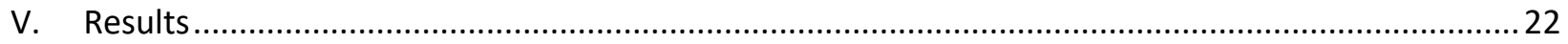

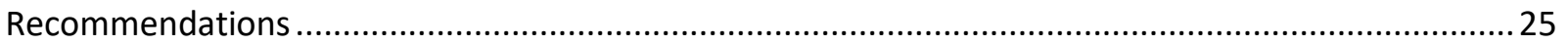

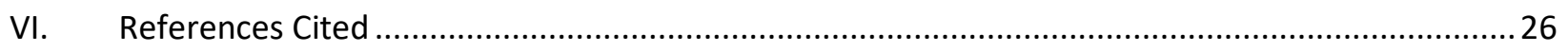

Appendix A: Texas Antiquities Permit 8878 and THC Concurrence Letter .......................................... A-1 


\section{List of Figures}

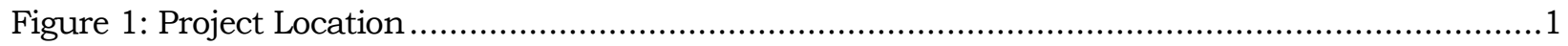

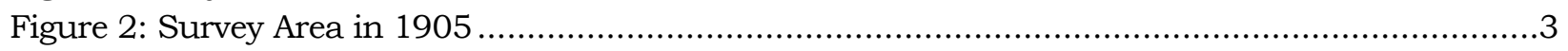

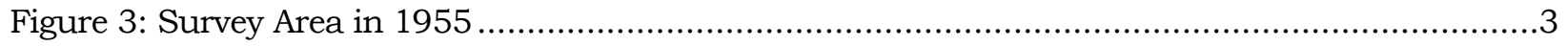

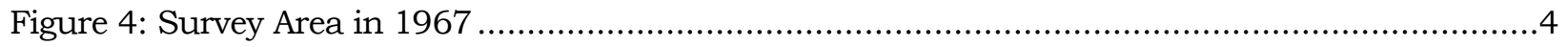

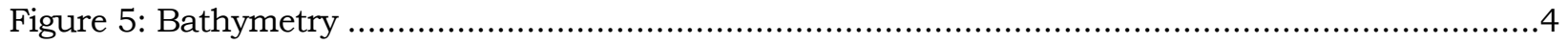

Figure 6: Example of a Verified Shipwreck Anomaly, Site 41CL92 ….....................................17

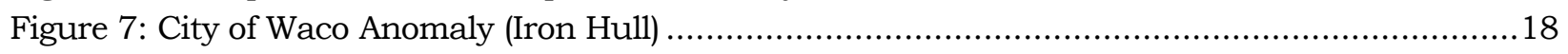

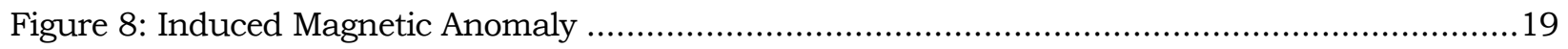

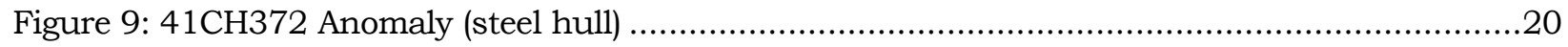

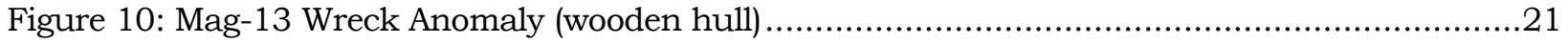

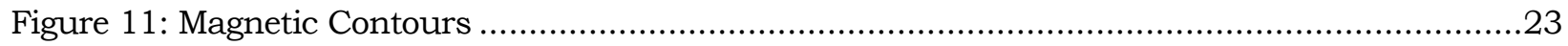

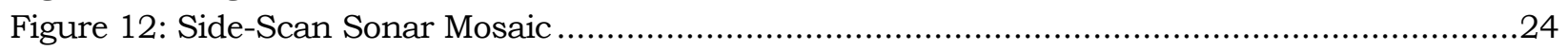

\section{List of Tables}

Page

Table 1: Wrecks Reported Within Three Miles of the Survey Area ............................................11

Table 2: Terrestrial Archaeological Sites Bordering the Survey Area ........................................13 


\begin{abstract}
BOB Hydrographics, LLC (BOB) conducted an underwater archaeological survey for proposed dredging adjacent 16628 Market Street in Channelview, Texas. The project is located upstream of River Terrace Park on the northern bank of Old River, an oxbow channel of the San Jacinto River, in Harris County. This project was sponsored by 16628 Market Street, LLC. The project spans portions of State Mineral Lease, Old River Tract A. An area of 3.5 acres is proposed for dredging to provide consistent depths for barge fleeting. Water depths in the survey area range from 3.5 to 15 feet. Dredging will remove sediment to an approximate depth of 12 feet, including shoals along the shoreline, allowing barges and tugs to moor along the existing bulkhead. The survey area measures 8.8 acres, including navigable portions of a 50meter buffer around the project perimeter but excluding areas where survey was prohibited by parked barges. Field investigations consisted of a marine geophysical survey, performed under Texas Antiquities Permit 8878, on May 8, 2019. The purpose of BOB's survey was to locate potential archaeological sites that would be affected by construction activities A desktop review of the cultural background determined that 10 marine archaeological investigations, 1 archival study, and at least 27 shipwrecks have been reported within 3 miles of the survey area. Magnetometer data was inconclusive due to abundant modern anomaly sources in the vicinity. Analysis of side-scan sonar data discovered no significant targets. BOB recommends clearance of the 3.5-acre project proposed for dredging from further cultural resource requirements. This study was completed in compliance with Section 106 of the National Historic Preservation Act (Public Law 89-665; 16 U.S.C. 470) and the Antiquities Code of Texas (Texas Natural Resource Code, Title 9, Chapter 191). The minimum reporting and survey requirements for marine archaeological studies conducted under a Texas Antiquities Permit are mandated by The Texas Administrative Code, Title 13, Part 2, Chapters 26 and 28, respectively. Project records are curated at the Center for Archaeological Studies at Texas State University in San Marcos. No artifacts were collected during this survey.
\end{abstract}




\section{Introduction}

BOB Hydrographics, LLC (BOB) conducted an underwater archaeological survey for proposed dredging adjacent 16628 Market Street in Channelview, Texas (Figure 1). The project sponsor, 16628 Market Street, LLC, contracted with BOB to conduct this archaeological assessment. An area of 3.5 acres is proposed for dredging to provide consistent depths for barge fleeting. Water depths in the survey area range from 3.5 to $15 \mathrm{feet}$ ( $\mathrm{ft}$ ). Dredging will remove sediment to an approximate depth of $12 \mathrm{ft}$, including shoals along the shoreline, allowing barges and tugs to moor along the existing bulkhead. The survey area measures 8.8 acres, including navigable portions of a 50-meter $(\mathrm{m})$ buffer around the project perimeter but excluding areas where survey was prohibited by parked barges. The project spans portions of State Mineral Lease, Old River Tract A. Cultural resources investigations were required because proposed dredging-related activities might affect historic cultural resources resting on or embedded in the seafloor. The results reported in this document will support the sponsor's application for a United States (U.S.) Army Corps of Engineers Permit.

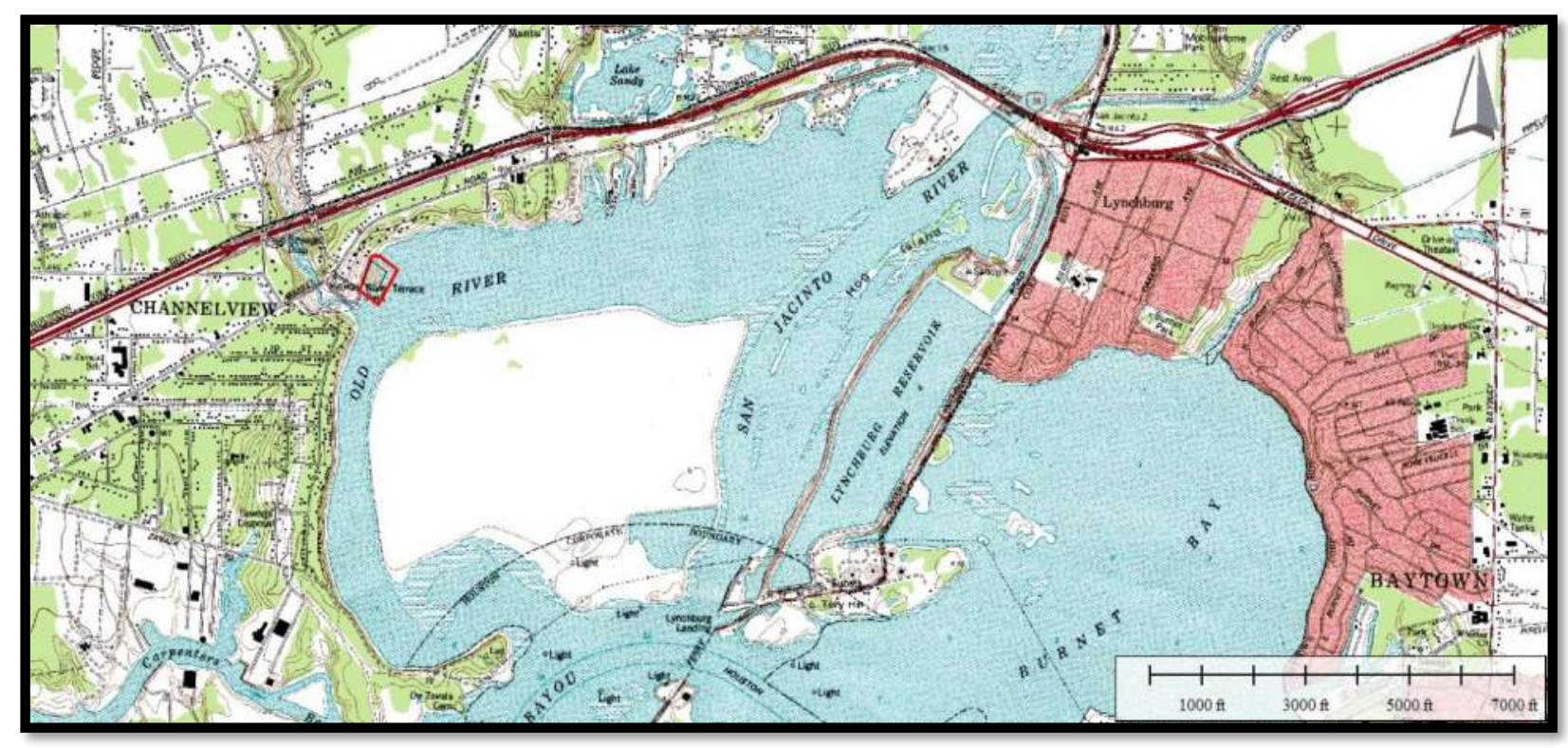

Figure 1: Project Location

Survey Area (outer, red polygon); Proposed Dredging (inner, shaded polygon) Base Map: Highlands, TX 7.5' U.S. Geological Survey (USGS) Quadrangle, 1982

The purpose of this study was to assess the potential of the survey area to contain submerged archaeological sites. Submerged archaeological sites, in this context, might be sunken or abandoned watercraft, remnants of historic shoreline developments, or submerged prehistoric sites. Submerged sites may be eligible for nomination to the National Register of Historic Places (NRHP) or as State Antiquities Landmarks. Geophysical survey was completed on May 8, 2019 by Robert Gearhart (Principal Investigator) and Michael Baxter. The Principal Investigator was solely responsible for archaeological data analysis. An archaeological assessment was conducted of all geophysical data acquired by the survey. 
A desktop review of the cultural background determined that 10 marine archaeological investigations, 1 archival study, and at least 27 shipwrecks have been reported within 3 miles of the survey area. Magnetometer data was inconclusive due to abundant modern anomaly sources in the vicinity. Analysis of side-scan sonar data discovered no significant targets. BOB recommends clearance of the 3.5-acre area proposed for dredging from further cultural resource requirements.

This study was completed in compliance with Section 106 of the National Historic Preservation Act (Public Law 89-665; 16 U.S.C. 470), requiring that the lead agency consider the effects of projects, receiving either permits or funding from the federal government, upon historic resources. This study also complies with the Antiquities Code of Texas (Texas Natural Resource Code, Title 9, Chapter 191), which provides for the protection of cultural resources on state lands. The survey area is publicly owned; therefore, Texas Antiquities Permit 8878 was obtained prior to beginning fieldwork. Title 13, Part 2, Chapters 26 and 28 of The Texas Administrative Code mandates the minimum reporting and survey requirements, respectively, for marine archaeological studies conducted under Texas Antiquities Permits. Project records are curated at the Center for Archaeological Studies at Texas State University in San Marcos. No artifacts were collected during this survey.

This report is organized into six sections that provide context for interpreting the survey results and includes maps of magnetic contours and side-scan sonar imagery. Section II relies upon a combination of published literature and data collected by this survey to summarize the physical environment of the survey area. Section III summarizes the relevant cultural background within a 3-mile radius of the survey, including maritime history, previous archaeological investigations, and the potential for intact archaeological sites. Section IV summarizes methods for conducting the geophysical survey and for processing and analyzing the resulting data. Section $\mathrm{V}$ presents an archaeological assessment of the geophysical data and provides recommendations specific to archaeological findings within the survey area. Bibliographic references cited in the text are included as Section VI.

\section{Physical Environment}

The survey area is located in an abandoned meander of the San Jacinto River called Old River. Old River has been cut off from the main channel of the San Jacinto River since, at least, the early 19th century (Texas General Land Office 1847). The survey area has been overlaid on historic charts from 1905, 1955 and 1967 in figures 2-4 to demonstrate land use changes. Aerial photography also was examined on Google Earth for the years 1944, 1953, 1978, 1989, 1995, and 2002 to 2019. The surrounding land appears to have transitioned from agricultural to residential use during the first half of the 20th century. By 1967 a levee had been built along the north side of Lost Lake to contain sediment dredged from the Houston Ship Channel, but the northern and western shorelines of Old River remained residential. Most residential properties were fronted by long piers, presumably used for recreation. The shoreline appears to have remained in residential use until 2008. By 2009, the property had been converted to industrial use, resembling the footprint of 2019 , with multiple barges parked along the waterfront. Barge fleeting had increased markedly in the area by 2015. 


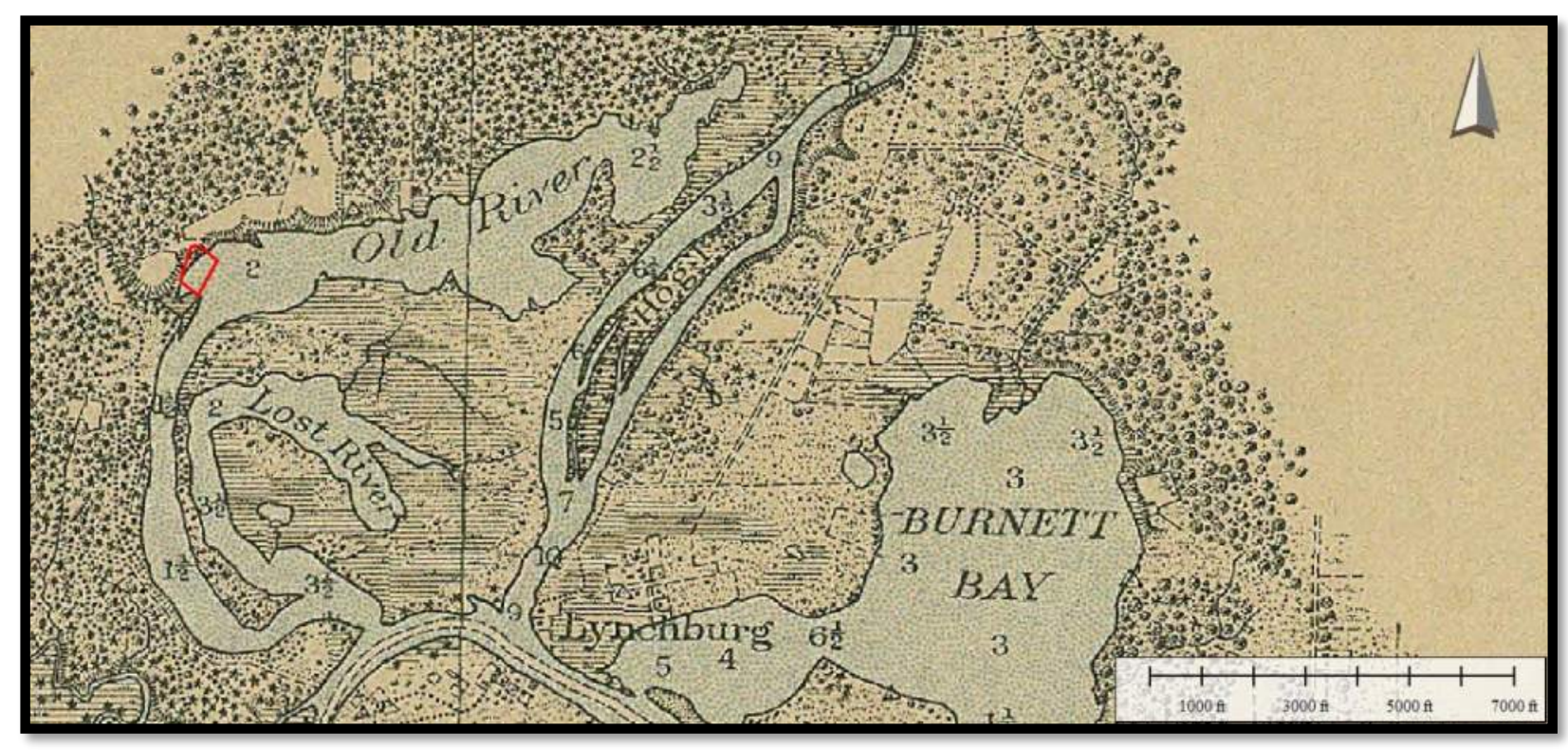

Figure 2: Survey Area in 1905 (Corps of Engineers 1905)

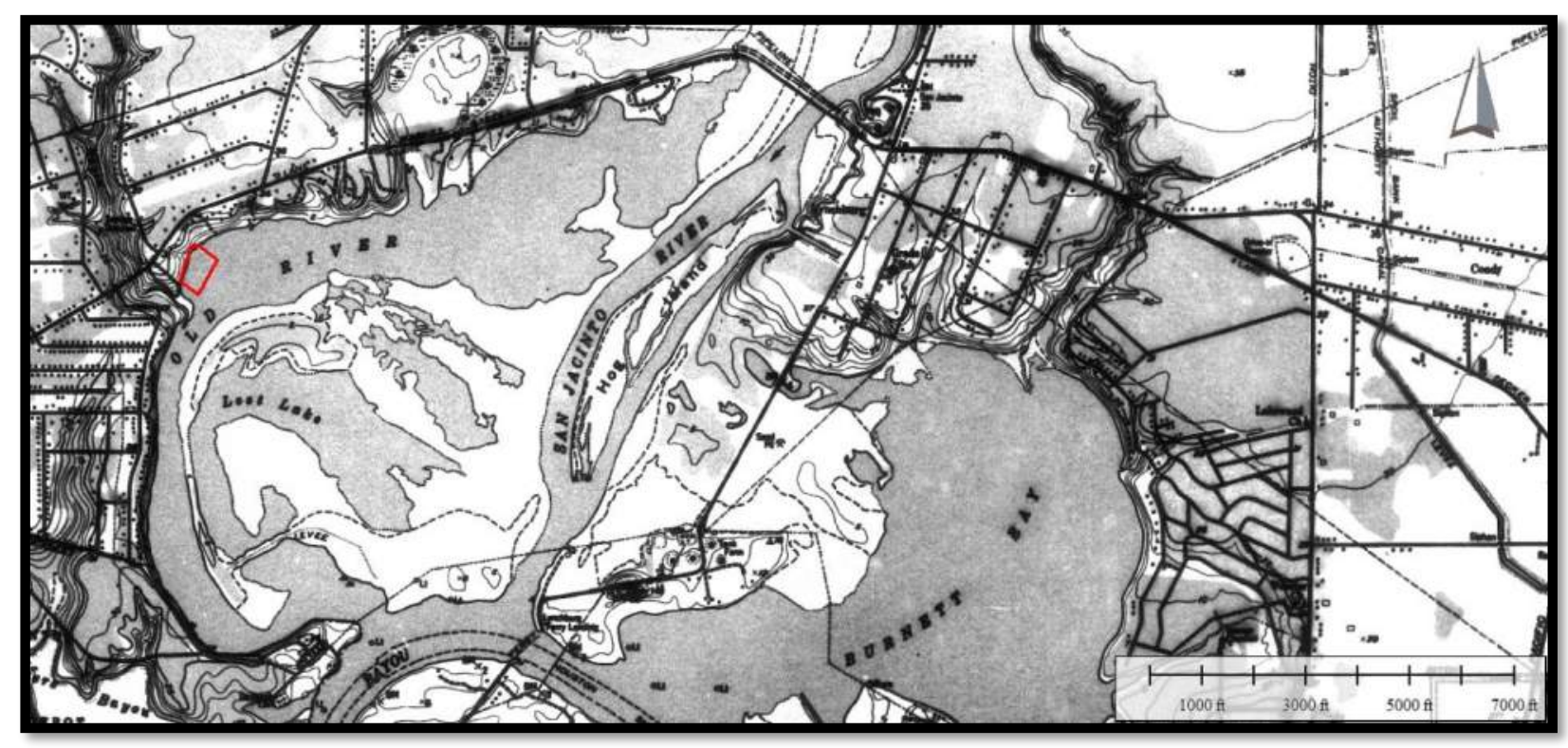

Figure 3: Survey Area in 1955 (USGS 1955) 


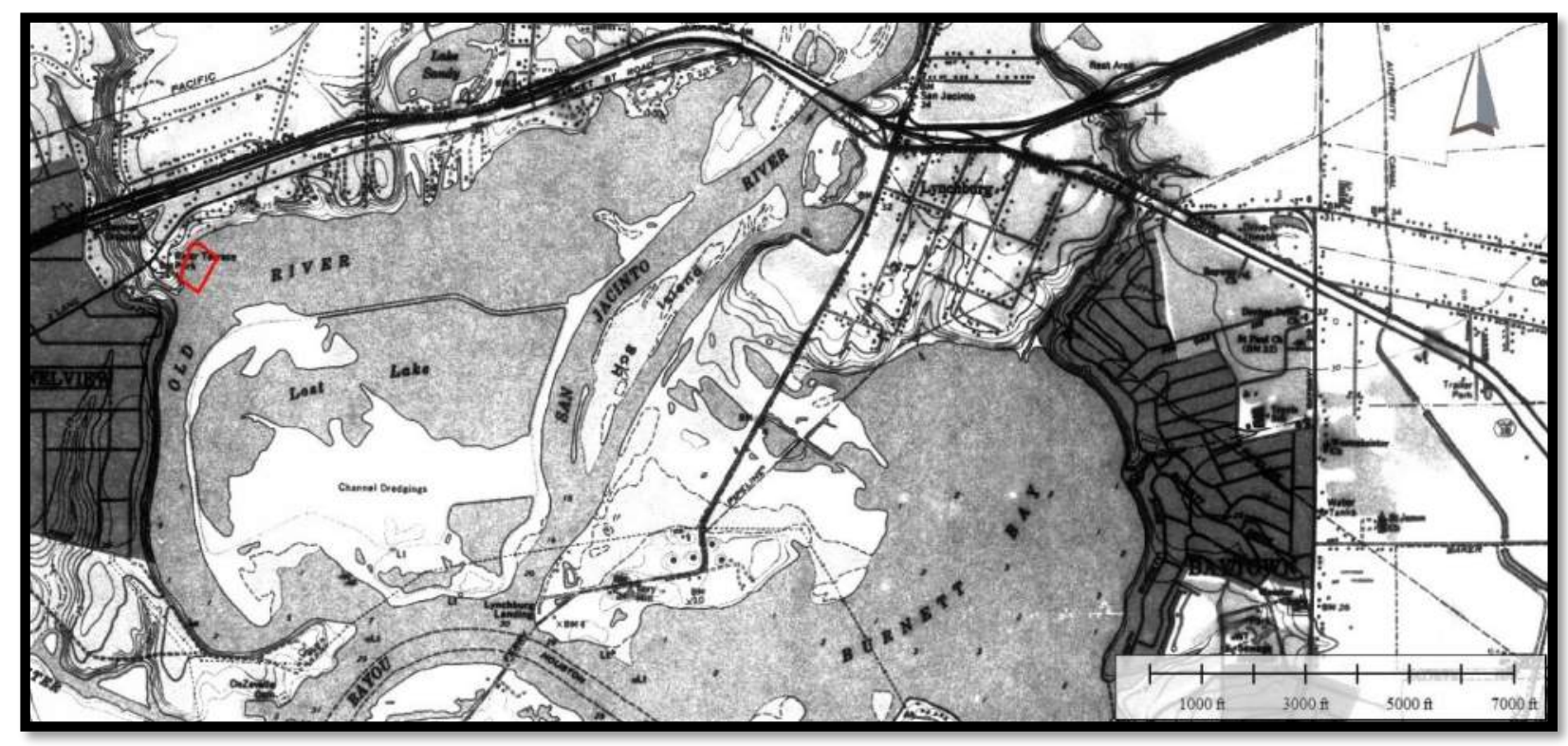

Figure 4: Survey Area in 1967 (USGS 1967)

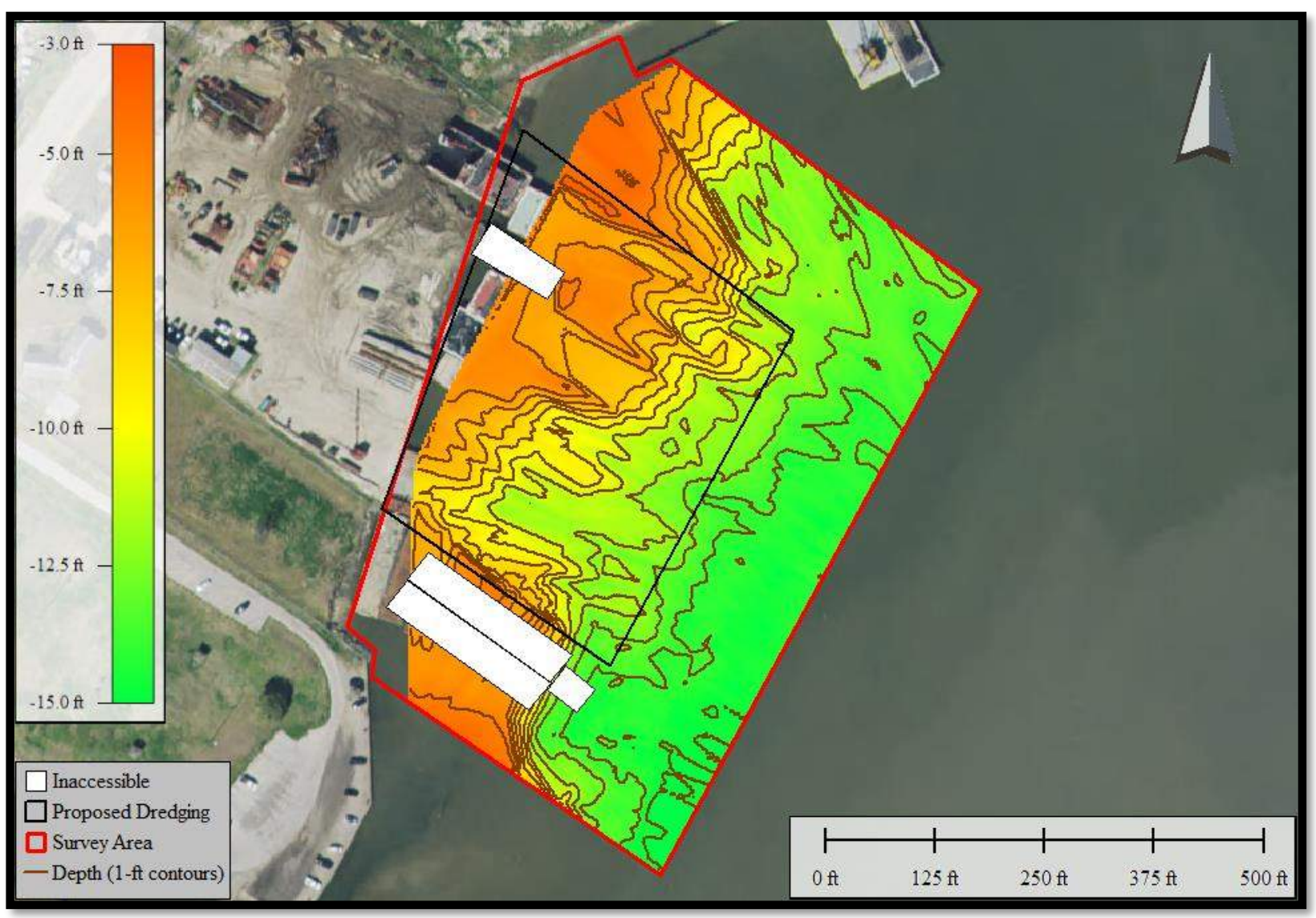

Figure 5: Bathymetry (Base 2015 DOQQ aerial) 
Water depths for Old River are not shown on most historic charts; however, depths of 1.5-2 $\mathrm{ft}$ were charted in 1905 (Figure 2). Old River likely was navigable only by very shallow draft boats throughout the historic period; however, land in this area has subsided substantially over the past century due to withdrawal of groundwater in the Houston metropolitan area. A study by the USGS documented about $5.5 \mathrm{ft}$ of subsidence in the survey area vicinity from 1943-1973 (Gabyrsch and Bonnet 1977: 10-14). Their study relied largely on data from the National Geodetic Survey leveling program. An additional $0.6 \mathrm{ft}$ of subsidence may have occurred from 1906-1943, although their data for that period is less abundant. Thus the 2-ft depths of 1905 would have subsided to about $8 \mathrm{ft}$ by 1973. Bathymetry acquired during this study is overlaid on a 2015 Digital Orthophoto Quarter Quadrangle (DOQQ) aerial photograph (top15-nc-cir50cm_2995163_20150209.jp2) in Figure 5. Depths reported in Figure 5 are not tidally corrected and were acquired during a period of abnormally high water, flooding the boat ramp at nearby River Terrace Park.

\section{Cultural Background}

Spanish claims to the Galveston area began in 1519, when a Spaniard named Alonso Alvarez de Piñeda led an expedition, on behalf of the governor of Jamaica, to map lands bordering the Gulf of Mexico. Piñeda produced the earliest known map of the Gulf of Mexico showing major inlets along its coast. There is no reliable evidence that he explored inland of the Texas Coast, but, at the least, he demonstrated there was no shortcut to Asia through the Gulf of Mexico (Chipman and Joseph 2010: 24-25).

The first Europeans known to explore the Texas Coast inland were survivors from the shipwrecked Pánfilo de Narváez expedition of 1527. Álvar Núñez Cabeza de Vaca and 80 other Spaniards sailed on rafts to what many believe was Galveston Island. Those who survived the first winter were enslaved by Native Americans. Only four men returned to tell their stories of wandering from tribe to tribe through what is now Texas and northern Mexico to the Pacific Coast, eventually reaching Mexico City after eight years. Cabeza de Vaca published his story in 1542 upon returning to Spain (e.g., Cabeza de Vaca 2013).

In 1682, a French expedition, led by René Robert Cavelier, Sieur de La Salle, traveled down the length of the Mississippi River to its mouth, claiming the Louisiana Territory on behalf of King Louis XIV and France. La Salle was partially following in the footsteps of the Spaniard Moscoso down the lower Mississippi, albeit in a much more deliberative manner. The French territorial claim established by La Salle extended to much of what later became the Louisiana Purchase. La Salle returned to the Gulf Coast by ship in 1685 intent on establishing a permanent colony near the mouth of the Mississippi River. Unfortunately for La Salle and his 300 colonists, they missed the Mississippi River and arrived, instead, at Matagorda Bay on the Texas Coast.

Spain mounted an intensive exploration of the Texas Coast to find and rout out the unwelcome intruders while simultaneously charting their own, relatively unknown, possessions there. Weddle (1991:68) summarized the effect of La Salle's arrival on the Spanish royal court as inspiring "the most intense coastal reconnaissance ever made in the Gulf of Mexico. In five coastal voyages spanning three years, there were few rivers and bays that had not been examined." One small part of their search for La Salle resulted in one of the earliest European encounters with Galveston Bay. 
An expedition led by Martín de Rivas and Pedro de Iriarte departed Veracruz on December 25, 1686 in search of La Salle. They sailed clockwise along the Gulf Coast with instructions to sail only by day, keep within sight of land, and enter all bays and rivers until they reached the supposed latitude of the reputed Espíritu Santo Bay or the Mississippi River. Along the way, on April 3, 1687, they discovered wreckage of a French ship (La Belle) in Matagorda Bay, which they correctly presumed to have belonged to La Salle. Unknown to Rivas and Iriarte, La Salle had died two weeks before their discovery, and the remnants of his colony were clinging to life only a few miles upstream from them.

Rivas and Iriarte continued on their expedition, after discovering La Belle, to rule out other locations along the northern Gulf Coast and to find the River "Micipipi" on which the French reportedly were intent upon establishing a settlement. Along the way they entered San Luis Pass, which they called Santa Suzana, in mid-April. Continuing along the coast, they encountered the main mouth of Galveston Bay. Discouraged by shoals, they spent little time exploring but returned on April 25 for a closer inspection. They sailed inland to a point of land believed to be Eagle Point but found no evidence of prior European visitors (Weddle 1991: 52-70).

Jean Baptiste Bénard de La Harpe produced the earliest detailed map of Galveston Bay in 1721. La Harpe intended to reestablish La Salle's abandoned fort, but he unknowingly arrived at the wrong bay. While in Galveston Bay, La Harpe met a French sailer named Francois Simars de Bellisle, an officer from the French ship, Maréchal d'Estrée that stranded near the entrance to Galveston Bay in 1719 (Folmer 1940). The ship was later floated, but Bellisle and a small group of officers elected to stay behind. He was the sole survivor the group. Bellisle was a slave to Native Americans for over a year during which time he wandered Coastal Texas from Galveston Bay to Fort Saint-Jean-Baptiste at present-day Natchitoches, Louisiana (Folmer 1940).

Galveston was settled soon after the Louisiana Purchase of 1803. Privateers based their operations on Galveston Island and Point Bolivar, supported by French, Mexican and Anglo-American interests seeking to overturn Spanish control of the region. Louis-Michel Aury operated from Galveston Island beginning in 1816 during the Mexican War for Independence. Aury, with the support of Mexicans in New Orleans, organized Galveston's first government, declared the town an official port of the Mexican Republic, and began raiding Spanish shipping. Within a year, Aury led an attack in Mexico with over 700 troops. While he was in Mexico, Jean Lafitte took over Aury's Galveston fort. James Long declared a Texas Republic in 1819 and installed Lafitte as governor of the island. Lafitte was forced from the island in 1821 when the U.S. government enforced a policy against piracy in the Gulf of Mexico (Davis 2005:419-420).

In 1824 Stephen F. Austin encouraged the newly independent Mexican government to settle Galveston in order to facilitate the shipment of cotton to England. Lands surrounding Buffalo Bayou were settled as part of Austin's “Old Three Hundred" Colony by 1824 (Foster, et al. 2007). Nathaniel Lynch received a Mexican Land Grant and established Lynch's Ferry on the San Jacinto River in 1822 (Wagner 2011). He later moved the ferry upstream from Crystal Bay to what became the town of Lynchburg. The Congress of Mexico established a port of customs at Galveston in 1825 (Cotham 1998:1; Francaviglia 1998:91, 95). 
The Battle of San Jacinto was fought in 1836 on the south side of Buffalo Bayou, immediately opposite the entrance to Old River. Lorenzo de Zavala, the first vice president of the Republic of Texas, had a home on the north bank of Buffalo Bayou, at its confluence with Old River. Zavala's home was used as a hospital following the Battle of San Jacinto. Zavala died in November 1836, shortly after resigning the vice presidency, and was buried in his family cemetery on Buffalo Bayou. Both the Zavala cemetery and home have since been washed away by subsidence and erosion of the Buffalo Bayou shoreline (Estep 2010).

Galveston was incorporated as a city late in 1836 after Texas won independence from Mexico, and within two years, Galveston became the largest source of cotton shipped to the East Coast and Europe. Houston was founded that same year by the Allen brothers on the banks of Buffalo Bayou. They began to clear snags and obstructions from Buffalo Bayou as early as the 1840s. Downstream from Buffalo Bayou, the San Jacinto River flowed into Galveston Bay over a small deltaic feature known as Clopper's Bar (U.S. Coast Survey 1852). The bar was an obstacle and a hazard to navigation between the river and the bay. All vessel traffic between Galveston Bay and points upstream, including Buffalo Bayou, had to cross Clopper's Bar.

Houston leaders soon recognized the need for navigational improvements along Buffalo Bayou to attract commerce inland from Galveston. The Buffalo Bayou Ship Channel Company made the first attempt to improve a channel across Galveston Bay in 1869 by cutting a channel through Morgan's Point to bypass Cloppers Bar. The project encountered financial difficulties and was forced to sell to Charles Morgan. Morgan Line steamboats already had been making regular runs between New Orleans and the Texas Coast since the Civil War, subsidized by federal mail contracts. The Morgan Line offered the only regular steamship service along the Texas Coast. Morgan's company would complete the canal through his namesake point and then go on to dredge the first channel across Galveston Bay. Meanwhile, the Rivers and Harbors Act of 1870 funded a survey for a federal ship channel extending across Galveston Bay to Buffalo Bayou, recognizing that Houston was becoming a major railway hub. Houston was granted status as an official federal port of entry that same year (Alperin, 1977).

Morgan built a marine and rail terminal at Clinton Island, on Buffalo Bayou and completed a 12-ft-deep channel leading from Morgan's Point to Clinton by 1874. The first deep-draft ship to pass through what is now the HSC was the Morgan Line steamer Clinton in 1876. Morgan charged a toll for passage on his ship channel until it was sold to the federal government when he died in 1878 (Foster et al. 1993: 48-50). Traffic seeking to avoid the toll, especially vessels traveling between Cedar Bayou and Houston, likely continued to utilize the old river route across Clopper's Bar. The Houston Ship Channel has been repeatedly deepened since the completion of Morgan's first channel to accommodate demand from ever larger vessels.

Channel improvements coincided with steady advancements in the safety of ships during the first half of the twentieth century. Sailing vessels were being replaced rapidly by safer, machine-powered vessels. By 1910, sailing ships comprised less than half of annual losses of U.S. merchant vessels for the first time, and by the end of World War II, only 2-percent of nationwide losses were sailing ships. This is significant, because sailing ships were at a higher risk of running aground than machine-powered vessels. At the same time that 
machinery was replacing wind power, more durable metal hulls gradually were replacing wooden hulls, a trend which had accelerated by the turn of the century. Nevertheless, at least 93 percent of all U.S. merchant vessels lost through the end of World War II were made of wood (Gearhart 2011a).

Old River appears to have remained a shallow bayou dominated by residential development until the late 1980s. Industrial development along Buffalo Bayou and the Interstate-10 corridor, combined with growth of Houston's population, may have prompted the transition of Old River from residential to industrial use. Prior to deepening of Old River by subsidence during the mid-twentieth century, there likely was little commercial navigation through the bayou, except to serve agricultural interests along its banks prior to its residential development.

\section{Previous Investigations}

Ten marine archaeological surveys and one archival study have been completed within 3 miles of the survey area.

In 1991, Espey, Huston \& Associates (EH\&A) surveyed a corridor adjacent each side of the HSC for the U.S. Army Corps of Engineers, Galveston District under Texas Antiquities Permit 1128, (Hoyt 1992). Their survey covered over 40 linear miles of ship channel from Bolivar Roads to the East Beltway 8 Bridge near Houston, plus 3.6 miles of the Galveston Ship Channel. They mapped over 3,400 magnetic anomalies and 570 sonar targets with the goal of finding shipwrecks and other historic sites that might be affected by future channel improvements.

A year later, EH\&A completed a companion archival research study of the same area (Foster, et al. 1993). This supplement to Hoyt's (1992) study delineated areas of potential archaeological and historical sites within and adjacent the ship channel based on historic records. Their research summarized 103 previously recorded archaeological, historical, and shipwreck sites and identified over 600 other potential historic sites within 1 mile of the channel. They made recommendations regarding high-priority sites and portions of the study area warranting further research and compiled a database of over 500 reported shipwrecks.

Between February and April, 1993, EH\&A conducted archaeological diving investigations at 23 localities along the HSC. These targets were selected for diving based on Hoyt's (1992) survey and Foster, et al.'s (1993) archival study. The project was performed on behalf of the U.S. Army Corps of Engineers, Galveston District under Texas Antiquities Permit 1194. Localities 1 and 2 were investigated within 3 miles of the present survey area. Locality 1 could not be relocated by additional survey. The anomaly source at Locality 2 was identified as two coils of discarded wire rope and a small piece of plate steel. No further investigations were recommended at either locality (Hoyt and Schmidt 1993: 23-29).

In 1994, EH\&A undertook a series of cultural resource investigations for the U.S. Army Corps of Engineers under Texas Antiquities Permit 1424 to study potential cultural resource localities along the HSC (Hoyt et al. 1998). That project included, in part, a close-order magnetometer survey of selected, previously defined areas along the HSC between the Beltway 8 Bridge and the outer end of the Galveston jetties. Results of those investigations revealed 242 historic site localities along the HSC. All localities were identified by name, type, age, potential archaeological integrity, potential NRHP eligibility, and research 
priority status. In addition, several hundred magnetic anomalies were identified during the remotesensing survey. Based on a correlation of anomalies with suspected historic site localities, recommendations were made for field examination of potential sites associated with the old Lynchburg town plat, the San Jacinto town plat, the industrial/commercial areas on San Jacinto River (near Old River), the Bayport Channel area, Red Fish Bar, and the Galveston Jetties.

In June, 1994, EH\&A completed a remote-sensing survey of five Beneficial Use Areas in Galveston Bay and the HSC for the U.S. Army Corps of Engineers, Galveston District under Texas Antiquities Permit 1529. EH\&A then compared survey findings with historic sites and shipwrecks identified by archival research reported by Hoyt, et al. (1998). One of the five areas surveyed, the 662-acre Goat Island Restoration Area, is about 3 miles south of the present survey. No significant targets were reported from their Goat Island Restoration Area survey (Hoyt, et al. 1995).

In 2006, a remote-sensing survey was conducted by Coastal Environments, Inc. on approximately 2.5 acres on the North side of the Interstate Highway 10 Bridge over the San Jacinto River. The survey was for the proposed new dolphin fender system to provide protection to the bridge pilings. No cultural resource sites were found. This survey was conducted under Texas Antiquities Permit 4191 (Pearson and Faught 2006).

In September 2009, Panamerican Consultants, Inc. of Memphis, Tennessee, conducted a remote-sensing survey for the Houston Fuel Oil Terminal Company under Texas Antiquities Permit No. 5400. Their survey was for the proposed Ship Dock Number 4 located in the HSC at the confluence of Buffalo and Carpenter Bayous in Harris County, Texas. A total of thirteen magnetic anomalies and twenty side-scan sonar targets were recorded in the survey corridor. The sources for all but two anomalies were visible on the surface or side-scan records. All anomalies were considered to represent non-historic manmade structures and no further work was warranted (James and Murray, 2009).

In January and February of 2010, PBS\&J performed a cultural resources assessment of data collected during a marine remote-sensing survey of Sneed Shipbuilding in Old River in preparation for construction of a proposed dry dock facility in Channelview. The marine remote-sensing survey was conducted over a two-day period, 29 January and 1 February 2010, by Chris Ransome \& Associates, Inc. Data analysis was performed by PBS\&J under the supervision of Principal Investigator Robert Gearhart. The results of the investigation revealed no magnetic or acoustic anomalies suggestive of potential submerged cultural resources within the area of impact. No further cultural resource investigations were warranted in conjunction with the project as proposed. All work was completed under Texas Antiquities Permit 5531 (Tubby, 2010).

In March, 2013, Atkins performed a marine remote-sensing survey for the proposed construction of a marine terminal for Vopak Terminal Deer Park, Inc. in Deer Park. Their survey area lies in Buffalo Bayou on the south side of the HSC, 1.8 miles west of its junction with the San Jacinto River. Atkins discovered no magnetic or acoustic anomalies consistent with verified shipwreck material and recommended that the survey area be cleared from further archeological consideration. Work was completed under Texas Antiquities Permit 6495 (Tubby, 2013). 
In December 2013 Bio-West, Inc. performed a nautical remote-sensing survey on behalf of Blanton \& Associates, Inc. in support of Enterprise Pipeline Company's Seaway Loop pipeline project in Crystal Bay and Scott Bay. Their survey was conducted under Texas Antiquities Permit 6729. The survey covered 340 acres and found no potential cultural resource sites. No further investigations were recommended (Hedrick, et al., 2014).

In 2018, ВOB conducted marine archaeological investigations on behalf of Schneider Engineering \& Consulting, Inc. and their client, HMS 850 Holdings, LLC. Their study supported environmental permitting for a proposed, 37-acre barge fleeting area near the eastern Lynchburg Ferry Landing and the entrance to Burnet Bay in Harris County. Field investigations included a marine geophysical survey of 102 acres and probing of one magnetic anomaly, both performed under Texas Antiquities Permit 8349. Probing and research determined that Anomaly 1 is associated with a buried wooden shipwreck, measuring $24 \times 108$ $\mathrm{ft}$. The Anomaly 1 Wreck (Site 41HR1223) is potentially eligible for the National Register of Historic Places. BOB recommended avoidance of $41 \mathrm{HR} 1223$ by $50 \mathrm{~m}$ and clearance of the remaining survey area, outside of the wreck avoidance boundary, from further cultural resource requirements.

\section{Potential for Historic Shipwrecks}

Europeans navigated the San Jacinto River since at least the early nineteenth century. Shipwrecks reported within 3 miles of the survey area are included in Table 1. Sources consulted for Table 1 include the Texas Historical Commission's (THC) Texas Archaeological Sites Atlas (Atlas); the National Oceanic and Atmospheric Administration's Automated Wreck and Obstruction Information System (AWOIS) database; a shipwreck database compiled by PBS\&J; and historic maps from the Texas Historical Overlay (Foster, et al. 2006). The THC Atlas contains reports of shipwrecks from historic records. The AWOIS database is maintained to support the charting of coastal areas. AWOIS tends to report recent shipwrecks; however, some historic wrecks are included. Positions for wrecks in AWOIS are usually more accurate than those from historic records, although positions pre-dating the era of satellite position systems can vary considerably from actual locations. A group of archaeologists, including this author, assembled the PBS\&J database, in part, based on information gathered from charts, historical reports, THC files, and AWOIS. The PBS\&J database focuses primarily on well-documented commercial wrecks postdating 1850 . There also is potential for unreported wrecks dating back to the time of early European navigation through the area.

The positions of most reported wrecks remain uncertain. Positions reported in historical accounts are often imprecise. Vessels reported as lost in the general vicinity may be included in Table 1 unless information exists to suggest a more precise position further than 3 miles from the survey area. At least 27 shipwrecks have been reported within a 3-mile radius of the survey area by one or more of the sources listed above. Only two of the wrecks listed in Table 1, sites 41HR1223 and 41HR1231, have been archaeologically verified.

\section{Factors Affecting Vessel Loss}

Factors contributing to the accidental loss of watercraft vary depending on environmental conditions. Historic government statistics, summarized by Gearhart, et al. (1990: Volume IV, 59-61), categorized vessel casualties, including most accidents and incidents resulting in injury or loss of property, and 
reported the value of losses incurred. A total loss was reported if the hull could not be saved. These statistics do not reflect the degree to which cargo and vessels were salvaged. Types of casualties included foundering, stranding, collision and other (including fires, boiler explosions, injuries, and mechanical failures, etc.).

Table 1: Wrecks Reported Within Three Miles of the Survey Area

\begin{tabular}{|c|c|c|c|c|c|c|}
\hline Name of Vessel & $\begin{array}{l}\text { THC } \\
\text { No. }\end{array}$ & $\begin{array}{c}\text { AWOIS } \\
\text { No. }\end{array}$ & $\begin{array}{c}\text { PBS\&J } \\
\text { No. }\end{array}$ & Type & Accuracy & Date Lost \\
\hline Ariel & 980 & - & - & river steamboat & 3 miles & 1830 \\
\hline C.M. Depew & 50 & - & - & river steamboat & 10 miles & 1961 \\
\hline Chippy & 2121 & 7115 & 402 & tug & high & Pre-1983 \\
\hline Fay & 2120 & 6969 & 396 & tug & high & Pre-1983 \\
\hline Louise & 2036 & - & 1271 & oil screw & - & 1942 \\
\hline Unknown & 1359 & 3041 & 228,378 & barge & - & Pre-1933 \\
\hline Unknown & 1364 & 3040 & 232,377 & barge & $1 / 4$ mile & Pre-1933 \\
\hline Unknown & 1368 & 3049 & 233,379 & barge & $1 / 4$ mile & Pre-1933 \\
\hline Unknown & 1918 & - & - & & $1 / 4$ mile & Pre-1933 \\
\hline Unknown & 2352 & - & - & & $1 / 4$ mile & Pre-1944 \\
\hline Unknown (41HR1223) & - & - & - & wooden hull & sub-meter & $\begin{array}{l}\text { Pre-Oct. } \\
1962\end{array}$ \\
\hline Unknown (41HR1231) & 2504 & - & - & unknown & sub-meter & Unknown \\
\hline Unknown & & 3037 & 374 & $\begin{array}{l}\text { sunken barges } \\
\text { used for docks }\end{array}$ & - & Pre-1951 \\
\hline Unknown & & 3039 & 376 & multiple barges & $1 / 4$ mile & Pre-1951 \\
\hline Unknown & & 7110 & 397 & barge \& tug & - & - \\
\hline Unknown & & 7111 & 398 & multiple barges & $1 / 4$ mile & Pre-1983 \\
\hline Unknown & & 7113 & 400 & barge & $1 / 4$ mile & Pre-1983 \\
\hline Unknown & & 7114 & 401 & barge & $1 / 4$ mile & Pre-1983 \\
\hline Unknown & & 7116 & 403 & multiple barges & $1 / 4$ mile & Pre-1983 \\
\hline Unknown & & 7117 & 404 & barge & $1 / 4$ mile & Pre-1983 \\
\hline Unknown & & 7118 & 405 & barge & $1 / 4$ mile & Pre-1983 \\
\hline Unknown & & 7119 & 406 & multiple barges & $1 / 4$ mile & Pre-1983 \\
\hline Unknown & & 7120 & 407 & tug & $1 / 4$ mile & Pre-1983 \\
\hline Unknown & & 7124 & 411 & spud barge, $5 \times 10 \mathrm{~m}$ & high & Pre-1983 \\
\hline Unknown & & 7125 & 412 & barge & high & Pre-1983 \\
\hline Unknown & & 7126 & 413 & multiple barges & high & Pre-1983 \\
\hline Unknown & & 7127 & 414 & barge & high & Pre-1983 \\
\hline
\end{tabular}

Intentional abandonment of watercraft due to age was not considered accidental loss, so statistics are unavailable. Nevertheless, intentional abandonment is a significant source of sunken historic watercraft, especially in backwater environments, such as Old River, where commercial navigation would be relatively unobstructed. The entrance to Old River would have been an attractive location for abandonment of decommissioned watercraft, prior to the period of its industrial development, due precisely to its dearth of 
commercial traffic. It's unlikely that commercial watercraft would have been abandoned in the survey area prior to the mid-twentieth century, because the channel between there and Buffalo Bayou was only 1.5-2 ft deep prior to the effects of subsidence.

Foundering was the primary mechanism of vessel loss in navigable waters. The Annual List of Merchant Vessels of the United States (U.S. Department of the Treasury 1906-1946) defined foundering as leaking or capsizing of vessels. Foundering accounted for about 6 percent of historic vessel losses. Despite its low rate of occurrence, recovery from foundering was less likely than from any other type of casualty. Fiftyfour percent of all foundered vessels were reported as totally lost.

Stranding was the primary mechanism of loss in shoal waters and was, by far, the most common type of shipwreck during the historic period. Stranding (or grounding) accounted for 64 percent of total losses reported by the U.S. Lifesaving Service for the period 1876 through 1914 (Gearhart, et al. 1990: Volume IV, 59-61). Stranding occurred where the water was too shallow for navigation, including shorelines, harbor bars and reefs. Forty-six percent of stranding events resulted in a total loss.

Severe weather accounted for 55 percent of total losses reported by the U.S. Lifesaving Service from 1876 through 1914. Almost half of all losses from foundering were caused by weather, compared with two thirds of losses from stranding. Mariners had short warning of approaching storms prior to modern weather forecasting. The Texas Coast can experience hazardous weather conditions throughout much of the year. Hurricane season lasts from late June through October. Hurricane-force winds can devastate ships caught unprepared. During the winter, severe cold fronts, or Northers, with winds exceeding 50 miles per hour and dangerous waves can affect the Texas Coast.

\section{Factors Affecting Vessel Preservation}

Preservation of sunken watercraft depends mainly upon their composition and the extent of their burial in the seafloor. Vessels may become partially buried soon after sinking due to the combined effects of storm-induced current scour, liquefaction of sediments, and their weight pressing down on a waterlogged substrate. Ships made of metal are equally susceptible to burial as wooden hulls, but metal hulls remain exposed much longer than wooden ones in saline waters along the Texas Coast. Exposed wooden components tend to disintegrate quickly where wood-boring organisms thrive. Biological organisms and water saturation weaken the wood, which is then more easily disarticulated and laid flat or removed by fishing trawlers and storm waves. Burial promotes long-term preservation of wood by creating an oxygendeprived environment, which limits biological activity. Given a sufficient quantity of weakly-consolidated sediment, a significant portion of a hull might become preserved in this manner.

Iron corrodes five times faster in seawater than when buried on land. Iron artifacts tend to become concreted when calcium carbonate from the seawater cements adjacent materials, such as rock and sand, or even other artifacts, to the iron object. Prolonged oxidation can leach out most or all iron mineral, leaving only a carbonate mold of the original artifact (Hamilton 1998). Iron and steel hulls, nevertheless, can survive seawater exposure for well over a century. 


\section{Potential for Submerged Terrestrial Sites}

Terrestrial archaeology sites nearest the survey area are listed in Table 2. One archaeological site, 41HR34, was reported adjacent the survey area; however, the site's name, Old River Island No. 1, suggests it might have been mis-plotted in Atlas. The potential for submerged sites in the survey area exists only near the shoreline where subsidence would have inundated a narrow strip of land during the twentieth century. The shoreline adjacent the survey area has been modified by industrial development, including installation of a sheet-pile bulkhead, thus it's unlikely that archaeological deposits would remain intact had they ever existed.

Table 2: Terrestrial Archaeological Sites Bordering the Survey Area

\begin{tabular}{|c|c|c|c|}
\hline Site & Age & Description & $\begin{array}{l}\text { NRHP } \\
\text { Eligibility }\end{array}$ \\
\hline 41HR25 & $\begin{array}{l}\text { Late } \\
\text { Prehistoric }\end{array}$ & $\begin{array}{l}\text { Rangia shell midden; No survey form; recorded by } \\
\text { Worthington and Neyland in 1956-57 as Old River No. } 2 \text { on } \\
\text { island north of Lost Lake; McGuff and Thomas reported in } \\
1973 \text { that an unknown portion had submerged; a } 25 \times 50-\mathrm{ft} \\
\text { area remained } 2 \mathrm{ft} \text { above water in } 1973\end{array}$ & undetermined \\
\hline 41HR34 & Unknown & $\begin{array}{l}\text { No survey form; recorded by Worthington and Neyland in } \\
1956-57 \text { as Old River Island No. } 1 \text {; this site, as plotted in } \\
\text { Atlas, is covered by an industrial site and the adjoining } \\
\text { shoreline has been modified to include a bulkhead; site } \\
\text { may be mis-plotted, since Atlas location is not on an island }\end{array}$ & undetermined \\
\hline 41HR35 & Unknown & $\begin{array}{l}\text { No survey form; recorded by Worthington and Neyland in } \\
1956-57 \text { as Channelview Park No. } 1\end{array}$ & undetermined \\
\hline
\end{tabular}

\section{Research Design}

\section{Survey Methods}

The purpose of the survey was to map geophysical anomalies that might indicate the presence of historically-significant, submerged archaeological sites. Submerged archaeological sites, in this context, likely would be historic sites, such as sunken or abandoned watercraft; although, drowned prehistoric sites may have become submerged in the vicinity due to subsidence. The primary instrument for locating submerged watercraft in buried contexts is the magnetometer. Exposed shipwrecks are most easily recognized in side-scan sonar imagery; however, historic wrecks in Texas bays and shallow areas in the Gulf of Mexico are more often buried. Vessels predating World War II tend to be constructed of wood, which quickly deteriorates when exposed to wood-loving organisms, common to warm saline environments. Nevertheless, buried wooden hulls can retain a high level of artifact preservation and historic integrity. Wrecks exposed above the mudline for more than a few years tend to be constructed of materials other than wood.

Geophysical survey was designed to meet or exceed the following minimum standards of the THC for archaeological survey of state-owned submerged lands (Texas Administrative Code, Title 13, Part 2, Chapter 28, Rule 28.6): 1) the survey must be conducted under a Texas Antiquities Permit issued by the THC; 2 ) the survey line interval cannot exceed 20 m (30 m when greater than 3 nautical miles offshore); 
3) bottom-disturbing activities must be avoided within $50 \mathrm{~m}$ of potentially significant targets (150 $\mathrm{m}$ when more than 3 nautical miles offshore); 3) the survey area must extend beyond the limits of bottomdisturbing activities by the width of the avoidance margin; 4) survey instrumentation must include a marine magnetometer, a high-resolution side-scan sonar, and a recording fathometer all of which must record data digitally to electronic storage media; 5) survey instrumentation should be interfaced with a positioning system having accuracy comparable or better than a differential global positioning system (GPS) receiver; 6) the magnetometer must be towed within $6 \mathrm{~m}$ of the marine bed and should sample at least once per second; 7) the side-scan sonar should operate at a minimum frequency of 300 kiloHertz $(\mathrm{kHz}) ; 8)$ the positioning system should sample at least once per second; and 9) no artifact collection is permitted.

The survey area measures 8.8 acres, including a 50-meter buffer around the perimeter, where navigable, but excluding areas where survey was prohibited by parked barges. The survey is located in State Mineral Lease, Old River Tract A. Water depth ranges from 3.5-22 at the time of the survey. The survey was completed by BOB on May 8, 2019 from a 20-ft hydrographic survey vessel. BOB's field crew included Robert Gearhart (Principal Investigator) and Michael Baxter.

Vector data, including sensor positions, water depth, and magnetometer, were logged in Hypack navigation software. Raster data, including side-scan sonar, were logged in Edgetech's Discover software. Geographic positions were acquired using a Trimble SPS785, differential GPS. Single-beam bathymetry data were acquired using a Teledyne-Odom CVM recording fathometer equipped with a $200-\mathrm{kHz}$ transducer. Lead-line soundings were used to calibrate the fathometer. A Geometrics 882 magnetometer was towed on the sea surface $50 \mathrm{ft}$ aft of the survey boat. Side-scan sonar data was acquired using a 600$\mathrm{kHz}$, Edgetech 4125 system towed from the survey vessel's port side. Horizontal position estimates for each sensor were recorded in real time.

Sonar imagery was recorded using Edgetech's Discover acquisition software. Geographic positions were embedded into the digital sonar data as it was recorded. Sonar data was recorded along a 25-m-wide (82$\mathrm{ft}$ ) swath overlapping with data from adjacent vessel tracks. Chesapeake SonarWiz software was used to combine sonar data from each transect into a composite sonar mosaic.

\section{Interpretation of Magnetometer Data}

Low-frequency fluctuations in magnetic data caused, for example, by diurnal passage of the sun or by geologic gradients were removed, prior to contouring, using a filter algorithm. The algorithm treats shortterm fluctuations, exceeding a selected threshold amplitude (0.5 nanoTesla [nT]), as anomalous values. The result is a dataset in which abnormally high and low magnetic amplitudes (anomalies) are centered around zero (representing the ambient level). All amplitude shifts, smaller than the threshold value, are reduced to near zero and are treated as ambient background. This process removes low frequency data, leaving potentially significant anomalies intact, and allows a visual representation of anomaly polarity.

Magnetometer data illustrated in this report have been thinned to a 1-second interval between data points. Diurnally-corrected magnetometer data was contoured using Blue Marble's Global Mapper ${ }^{\circ}$ software (Version 17.2) at a 5-nT contour interval. Magnetic amplitudes between $+5 \mathrm{nT}$ and $-5 \mathrm{nT}$ are 
considered insignificant. Contour maps omit the 0-nT contour level to prevent a cluttered appearance. Positive amplitude is indicated by red contours, and negative amplitude is drawn as blue contours.

Most magnetic anomalies in marine environments are caused by relatively small pieces of ferromagnetic debris, which tends to concentrate near high-traffic areas, marine disposal areas, industrial developments, petroleum wells, and pipelines. The frequency of ferromagnetic debris far outnumbers shipwrecks, necessitating some means for distinguishing between the two when conducting archaeological assessments. The method used here is based primarily upon a study by Gearhart (2011b) that compared shipwreck and debris anomalies.

Gearhart has analyzed magnetic data from a large and diverse collection of anomaly sources, including 39 verified shipwrecks (Gearhart 2011b, 2016) and many debris sources with the goal of characterizing differences between these two categories of magnetic sources. Shipwrecks in his dataset represent a broad spectrum of material compositions, construction styles, ages, and archaeological contexts. Their hulls include construction from wood, iron, steel, and concrete. Their propulsion systems range from sail to steam-driven paddlewheels and propellers, and from oil and diesel screws to towed or pushed barges. They range in age from the mid-16th to the mid-20th century. They have been found in diverse depositional environments including harbor entrances, surf zones, beaches, marsh, oyster reefs, open bay waters, and the Gulf of Mexico. And this assortment of watercraft found their way to the seafloor in various ways including stranding on beaches, foundering at sea, by fire, by explosions (both accidental and intentional), and by abandonment. Some were partially demolished or salvaged after wrecking. Others remain largely untouched since the day they sank. Yet despite their many differences, they share common characteristics, which form the basis for this interpretative method.

\section{Amplitude}

Anomaly amplitude correlates poorly with horizontal dimensions of a magnetic source, because amplitude depends greatly upon the mass of the source and the distance between the magnetometer and the source. Small sources can produce large amplitude when measured at close range. Shipwreck anomalies from Gearhart (2011b) have average peak-to-peak amplitudes of $270 \mathrm{nT}$ for wood-hulled sailing vessels $(n=6) ; 5,020 \mathrm{nT}$ for wood-hulled machine-powered vessels ( $n=7)$; and 10,386 nT for iron- and steel-hulled vessels $(n=12)$. Magnetic debris can produce amplitudes virtually anywhere within that same range, thus amplitude is of little use for differentiating shipwrecks from debris.

\section{Complexity}

Archaeologists frequently have described shipwreck anomalies as appearing "multicomponent" or "complex", while anomalies having simple, monopolar or dipolar shapes often were attributed to debris. Garrison, et al. (1989: II, 223) summarized several common methods for prioritizing anomalies with a focus on complexity. Shipwreck anomalies were characterized as having: multiple peaks of differing magnitudes spread over an area greater than 10,000 square meters (2.5 acres); gentle gradients; and a linear association with anomalies on adjacent transects. A typical debris anomaly was characterized as having a single peak covering an area of less than 10,000 square meters, a steep gradient, and no alignment of anomalies on adjacent lines. 
Some early observations of complexity in wreck anomalies pre-dated computer contouring software. One or more peaks were observed on each transect crossing a single anomaly, but the spatial relationships between those peaks were not apparent. This problem was compounded by the lower accuracy of positioning systems prior to GPS. Thus, even a simple dipole might appear more complex than it really was. Earlier magnetometer technology also might have contributed to the perception of complexity. Proton precession systems tended to produce false noise spikes in the presence of high magnetic gradients, which could be interpreted as complex patterns of amplitude peaks where none existed.

The collection of 39 anomalies from verified shipwrecks reported by Gearhart (2011b and 2016) indicate, contrary to earlier models, that shipwreck anomalies (in mid-northern latitudes) tend to be dominated by a single main dipole, oriented approximately in line with magnetic north (Figure 6, for example; also see "Orientation" below). In fact, most debris anomalies also tend toward simple, dipolar shapes, while some shipwreck anomalies have more than two amplitude peaks. The concept of complexity is insufficient, by itself, to differentiate shipwrecks from debris anomalies; although, this fact does not lessen the need to correct any remaining misconceptions that shipwreck anomalies are typically complex and debris anomalies are not. The truth is more complicated than that simple dichotomy.

Many wreck anomalies also have secondary amplitude peaks, in addition to their main, north-southaligned dipole. Secondary peaks typically have lower amplitude than the main dipole and cover a smaller area than the main dipole peaks in all examples known to this author. Secondary peaks can be caused in two ways. The combined mass of the wreck either induces secondary peaks, or they are directly associated with individual ferromagnetic sources in a debris field.

Secondary peaks can be induced by the magnetic field lines emanating from wreckage. In mid-northern latitudes, a smaller peak sometimes occurs immediately north or south of, and in line with, the main dipole (e.g., peaks labelled "A" in Figures 7, 8, and 9). Amplitude peaks of this nature are not necessarily located over an anomaly source and may not indicate the presence of widely-scattered wreckage. Rather they seem to be induced by a source of relatively high mass, such as a ferrous hull. In such cases, magnetic lines-of-force can loop so far to the north and/or south of a source that, respectively, they reinforce or diminish (i.e., are anomalous to) earth's field. The result is a small positive peak to the north and, occasionally, a smaller negative peak to the south of the main dipole. They will always have polarity opposite the adjoining peak of the main dipole. Such peaks are fairly symmetrical about an anomaly's north-south axis and will not overlap its main dipole. The inflection point between an induced secondary peak and the main dipole occurs where the anomaly's lines of magnetic force are perpendicular to earth's lines of force.

Other secondary peaks may be directly caused by relatively large, individual magnetic sources within or near a hull or debris field. If such a mass is sufficiently large, its anomaly might not be completely cancelled by neighboring sources, allowing it to stand out. A similar effect may be observed if a magnetometer passes sufficiently close to a complex source, such as a shipwreck, so that some large-mass sources, are individually expressed against the background of the main dipole field. Such debris-centric, secondary 

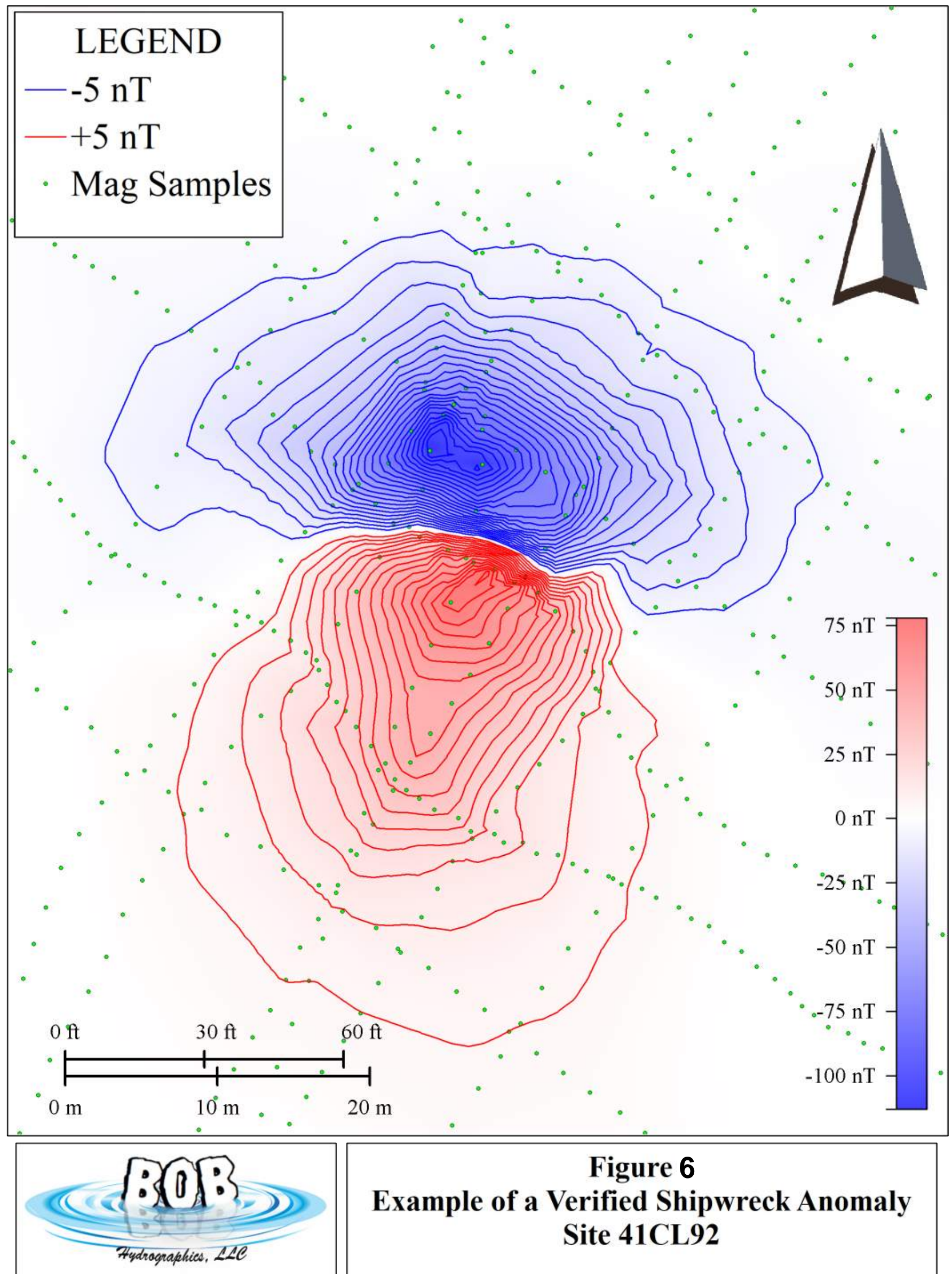

Figure 6

Example of a Verified Shipwreck Anomaly Site 41CL92 
peaks should have random orientations and positions, with respect to the main dipole, since they are directly caused by randomly-positioned objects within a debris field. They may overlie and disrupt the symmetry of the primary north-south dipole (e.g., peaks labelled "B" in Figures 7 and 8).

\section{Horizontal Dimensions}

Anomaly width, or duration as preferred by some, is a common and valid measure used by archaeologists for discriminating potential shipwreck anomalies from those believed more likely caused by debris. For example, Linden and Pearson (2014) would consider an anomaly significant if it has amplitude of at least $50 \mathrm{nT}$ and a width of $65 \mathrm{ft}$ or more. The horizontal dimensions of shipwreck and debris anomalies overlap considerably, especially when considering wrecks with wooden hulls, thus width alone is not particularly useful for discriminating between the two. There is a 15-fold difference in width between the smallest wood-hulled sailing ship and the largest steel tanker, so large wrecks tend to be obvious. Unfortunately, small, wooden watercraft, even many steamboats, tend to have anomalies no wider than many debris anomalies.

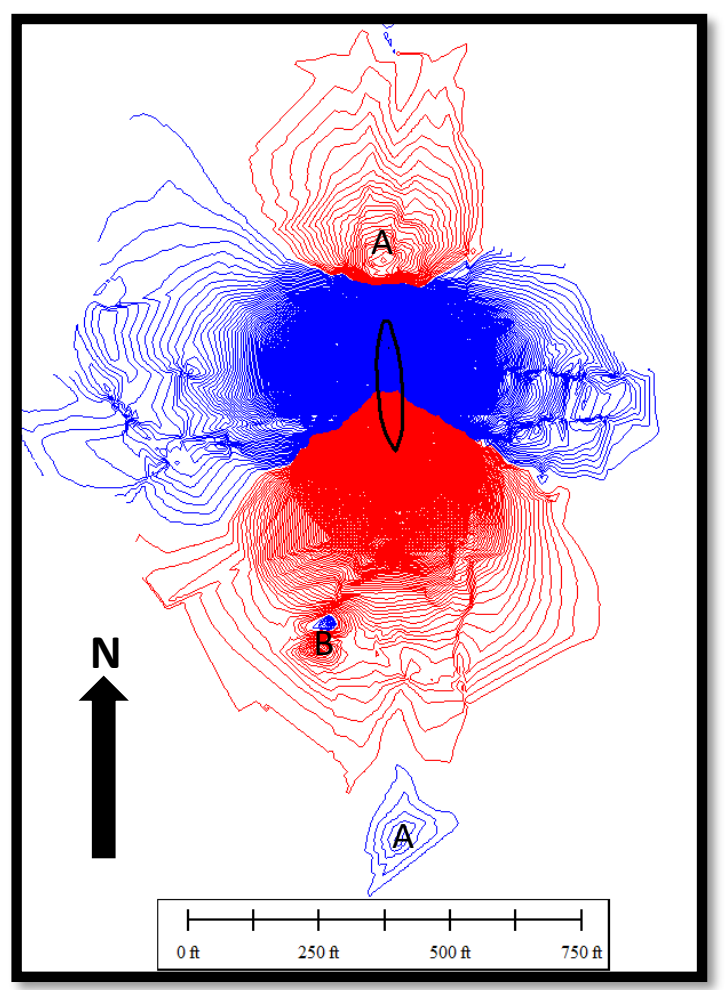

Figure 7: City of Waco Anomaly (Iron Hull)
Anomaly width, or duration as preferred by some, is a common and valid measure used by archaeologists for discriminating potential shipwreck anomalies from those believed more likely caused by debris. For example, Linden and Pearson (2014) would consider an anomaly significant if it has amplitude of at least $50 \mathrm{nT}$ and a width of $65 \mathrm{ft}$ or more. The horizontal dimensions of shipwreck and debris anomalies overlap considerably, especially when considering wrecks with wooden hulls, thus width alone is not particularly useful for discriminating between the two. There is a 15 -fold difference in width between the smallest wood-hulled sailing ship and the largest steel tanker, so large wrecks tend to be obvious. Unfortunately, small, wooden watercraft, even many steamboats, tend to have anomalies no wider than many debris anomalies.

Small shipwreck anomalies cannot be distinguished from debris anomalies based on size alone. All woodensailing-ship anomalies and all but one woodensteamboat anomaly known to this author are smaller than 10,000 square meters, Garrison, et al.'s (1989: II, 223) minimum suggested size for typical shipwreck anomalies. Site 41CL92 (Figure 6), for example, covers an area of only 1,580 square meters ( 0.4 acres) out to the $5-n T$ contour. Small, wooden, and generally historic, shipwrecks are the most difficult sites to detect precisely because their anomalies overlap in size with many debris anomalies. 
The smallest wreck, although not the smallest anomaly, in Gearhart's anomaly dataset, Mag-13 (Figure 10 ), is a wooden hull buried 2-10 ft below the seafloor. The hull measures roughly $35 \times 13 \mathrm{ft}$, based on diver probes (Gearhart 2016). The Mag-13 anomaly measures $197 \times 164 \mathrm{ft}(60 \times 50 \mathrm{~m})$ across. Site 41CL92 (Figure 6), although having larger site dimensions, has the smallest verified wreck anomaly known to this author, measuring $176 \times 155 \mathrm{ft}(53.6 \times 47.2 \mathrm{~m})$ to the 5-nT contour. Divers identified Site 41CL92 as an early 19th-century sailing vessel containing a large collection of concreted artifacts, iron bar stock, and pig iron ballast but with no hull remaining (Borgens 2004). Its debris field measures $52 \times 23 \mathrm{ft}(15.9 \times 7 \mathrm{~m})$ across.

The 41CL92 anomaly is smaller than the Mag-13 anomaly, even though the 41CL92 site dimensions are larger. Its smaller magnetic footprint might be due to its disarticulated nature, whereas the Mag-13 site appears to have an intact hull. The higher entropy of a disarticulated wreck, in theory, should result in a lower peak amplitude and a smaller magnetic footprint, all other things being equal, than if the same wreck were an intact hull. Unfortunately, the original hull dimensions of 41CL92 are unknown. Although it represents the smallest anomaly known to date for a disarticulated wooden wreck, smaller examples likely exist. A realistic lower limit for the dimensions of a significant anomaly remains open for debate.

The smallest likely size of historic commercial watercraft in the Gulf Coast trade can be determined through research. For example, the average size of wooden sailing vessels registered in the Port of New Orleans during the period $1804-1820$ was 71 x $21 \mathrm{ft}(21.6 \times 6.4 \mathrm{~m})$ (based on Works Progress Administration [1941] as summarized in Ford et al. 2008: 54-71). The smallest vessel registered in New Orleans during the same period was the schooner Tickler, which measured only $29 \times 10 \mathrm{ft}(8.8 \times$ $3.0 \mathrm{~m}$ ) (Works Progress Administration 1941: $127)$, roughly 80 percent the size of the Mag13 hull.

It seems reasonable, based on comparison with the Mag-13 wreck anomaly, that an intact wooden vessel as small as Tickler might have an anomaly measuring as small as $158 \times 131 \mathrm{ft}(48.2 \times 39.9 \mathrm{~m})$ across, about 87 percent the size of the 41CL92 anomaly (Figure 6). To be conservative, this author

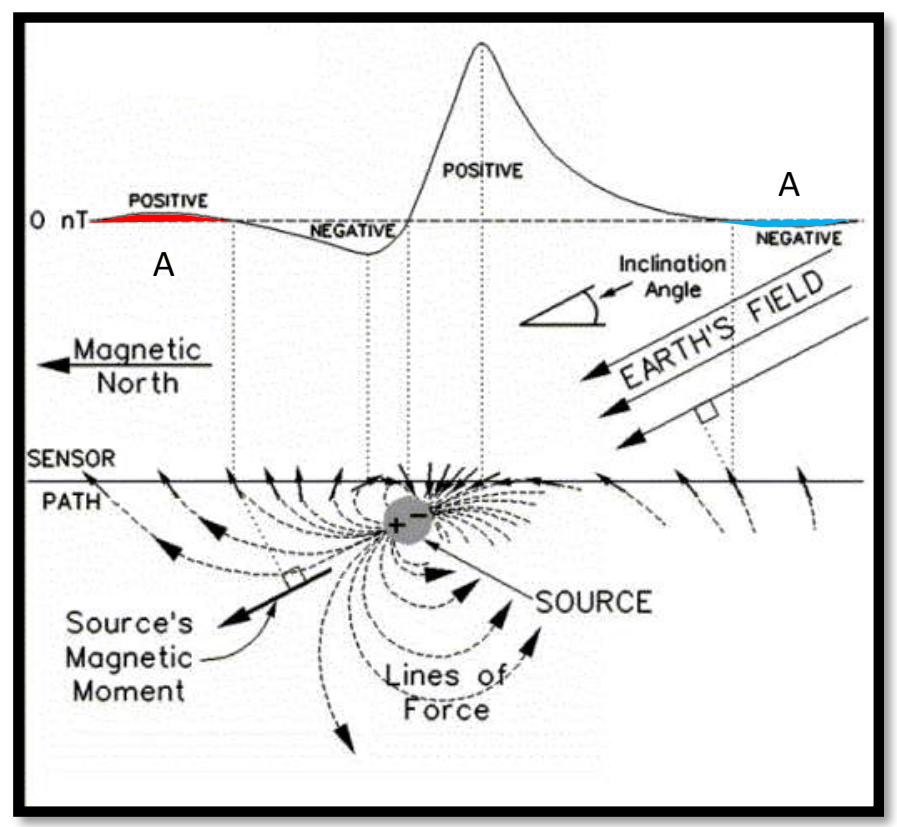

Figure 8: Induced Magnetic Anomaly will consider dipoles aligned with magnetic north as potentially significant if their minimum horizontal dimensions are at least $132 \times 116 \mathrm{ft}(40.2 \times 35.4 \mathrm{~m})$, which is 75 percent as large as the 41CL92 anomaly over a disarticulated, originally wooden, vessel and 86 percent the size of the hypothetical anomaly for an intact wooden vessel as small as Tickler. 


\section{Orientation}

Shipwreck anomalies (e.g., Figures 6, 7, 9, and 10) consistently share a common orientation with respect to earth's magnetic field, despite the great diversity of wrecks described above. All wreck anomalies observed by this author, to date, are oriented with their primary negative pole situated north of their positive pole. The local direction of magnetic north agrees, on average, within $+/-10$ degrees of the dipole alignment for 29 verified wreck anomalies, reported in Gearhart (2011b). The maximum reported difference between dipole alignment and magnetic north direction was 26 degrees. A similar orientation is expected of all wrecks, as well as all other complex anomaly sources, in mid-latitudes of the northern hemisphere; however, the orientation of anomalies over simple debris sources is not limited.

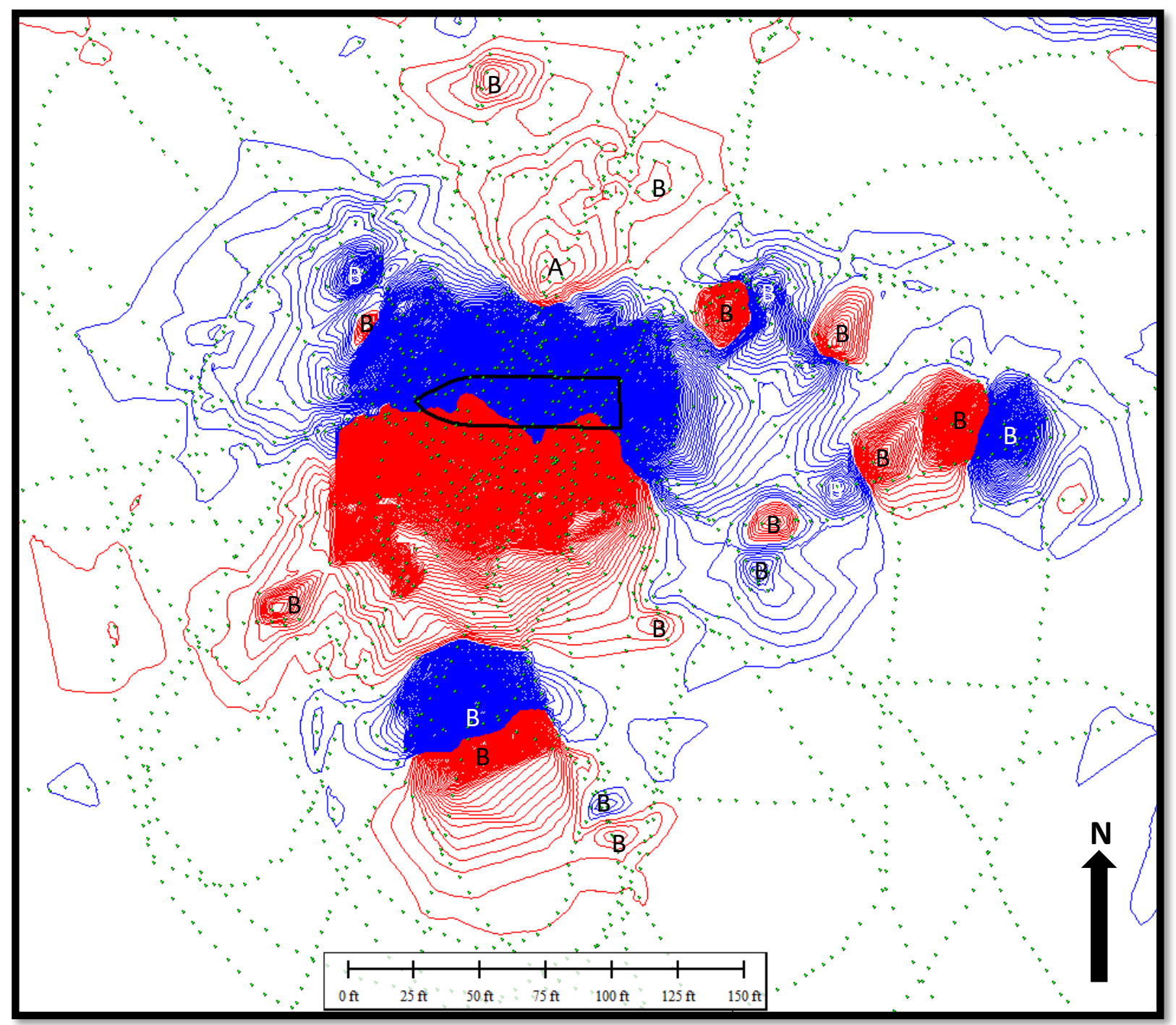

Figure 9: 41CH372 Anomaly (steel hull), 5-nT contour interval

Shipwrecks, and other complex sources, have anomalies closely aligned to the direction of magnetic north. This phenomenon is believed due to the random orientations of many individual magnetic components that make up each complex source, including shipwrecks. The magnetic field of each component interacts with that of its neighbors. The overlapping portions of fields that oppose one another in direction tend to 
cancel, while lines of force that run in the same general direction reinforce each other. Since a small portion of each field is aligned with (induced by) earth's local field, the net result of all these interactions is that more reinforcement occurs in the direction of magnetic north than in any other direction, resulting in a north-aligned anomaly. A simple debris source, on the other hand, is a solitary object on the seabed. By definition, there are no nearby sources affecting its magnetic field, thus the alignment of its anomaly is determined not by earth's magnetic field direction but by the object's orientation on the seabed. Hence debris anomalies can be oriented along any point of the compass.

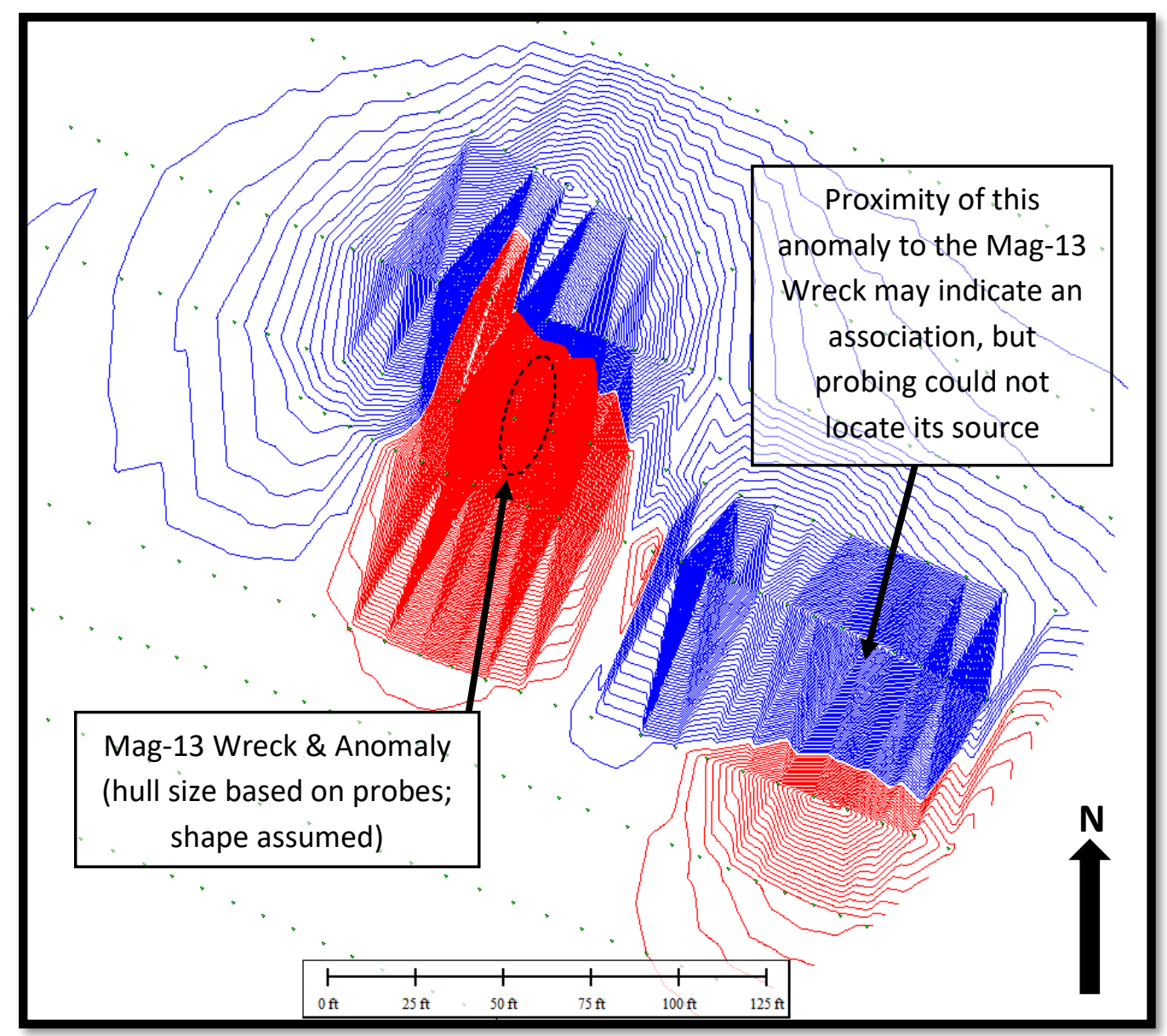

Figure 10: Mag-13 Wreck Anomaly (wooden hull)

5-nT contour interval (Gearhart 2016: 46)

Orientation can differentiate magnetic anomalies caused by most simple debris sources from anomalies caused by complex sources, including shipwrecks, and has potential to eliminate close to 80 percent of debris anomalies from further archaeological concern. Roughly 20 percent of simple debris sources have northerly orientations like those observed over complex sources. Absent a sonar target, there is no reliable method known, short of physically probing an anomaly, to differentiate that 20 percent of debris anomalies having northerly orientations from anomalies over complex sources, including potential buried shipwrecks. 
Anomalies can be eliminated from consideration as potential shipwrecks by demonstrating that their orientations differ substantially from the direction of magnetic north. It seems unlikely that a shipwreck could have a magnetic anomaly that is not aligned closely with magnetic north, as this would require a large percentage of the wreck's many ferromagnetic components, by chance, to have the same magnetic moment. On the other hand, the anomaly of a simple debris source should align with earth's magnetic field only when its magnetic moment, as determined by the source's orientation on the seafloor, closely aligns with magnetic north.

The interpretation of magnetic anomalies based on orientation requires comparing unidentified magnetic anomalies, contoured at a 5-nT interval, to the anomaly of a small, verified wreck anomaly, such as 41 CL92, shown in Figure 6. One must ensure that the reference anomaly is contoured, oriented and scaled using the same parameters as the survey data to which it is compared. Anomalies having a polar orientation similar to that of 41CL92 should be considered possible shipwrecks unless contradicted by other information, such as reliable evidence of an abandoned petroleum well nearby, as anomalies over steel well casings closely resemble shipwreck anomalies.

\section{Significance Criteria}

BOB's minimum criteria for archaeological assessment of magnetic anomalies (in mid-latitudes of the northern hemisphere) requires that a significant anomaly be consistent with the following conditions: 1) it must have at least one dipole, oriented with its negative pole north of its positive pole; and 2 ) it should be at least $124 \mathrm{ft}(37.8 \mathrm{~m}$ ) across (to the +/- 5-nT contour). An anomaly's shape usually is not obvious if data is from a single survey transect; thus, additional criteria have been designed to avoid missing significant targets. If survey lines are spaced at either 20- or 30-m intervals, a significant anomaly: 3) may be limited to a single transect; and 4) may appear as a monopole, provided the transect follows a predominantly east-west heading. If survey lines are spaced at 10-m intervals, a significant anomaly: 5) should appear on 3 or 4 transects; and 6) should measure at least $124 \mathrm{ft}$ ( $37.8 \mathrm{~m}$ ) wide orthogonally. Exceptions may be made, at the Principal Investigator's discretion, based on mitigating circumstances or professional judgment. Resemblance to verified shipwreck anomalies, including the 39 reported by Gearhart (2011b and 2016), should be an important factor in such judgments when close-order survey has been conducted.

\section{Results}

No significant geophysical targets were discovered by this survey. Magnetometer data and transects are illustrated in Figure 11, overlaid by pre-planned survey lines. Side-scan sonar data is illustrated as a mosaic image in Figure 12. Information regarding petroleum infrastructure was checked on the Railroad Commission of Texas' Public GIS Viewer. No wells or pipelines are reported near the survey area. Magnetometer data was affected unavoidably by proximity of the sensor to several large magnetic sources. Identifiable sources of magnetic anomalies included a steel, sheet-pile bulkhead along a portion of the shoreline; a partially disassembled barge on a marine ways; a partially submerged crane barge; and barges and tugs, moored as indicated in Figure 11. All floating barges were moved from the area proposed 


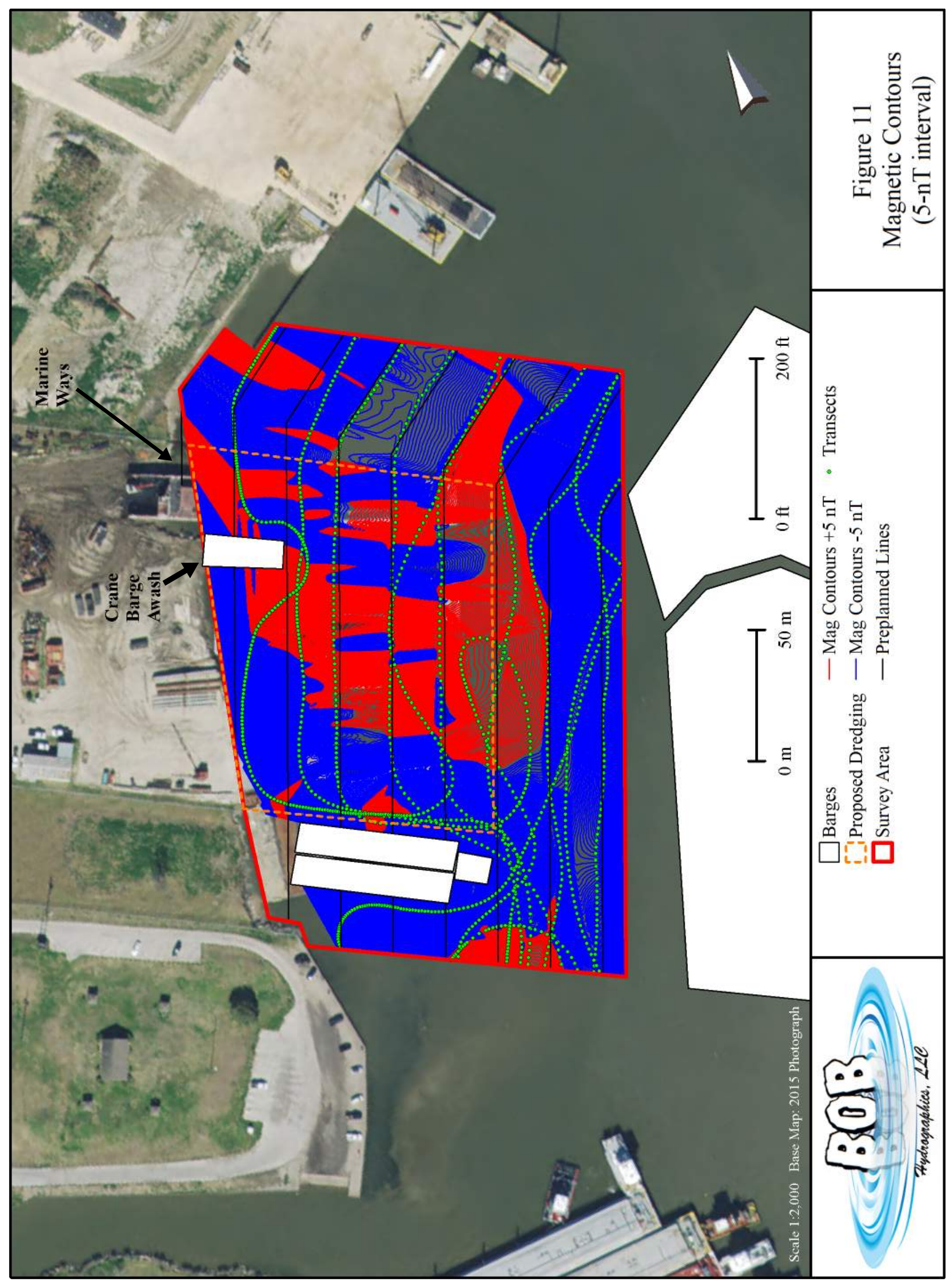




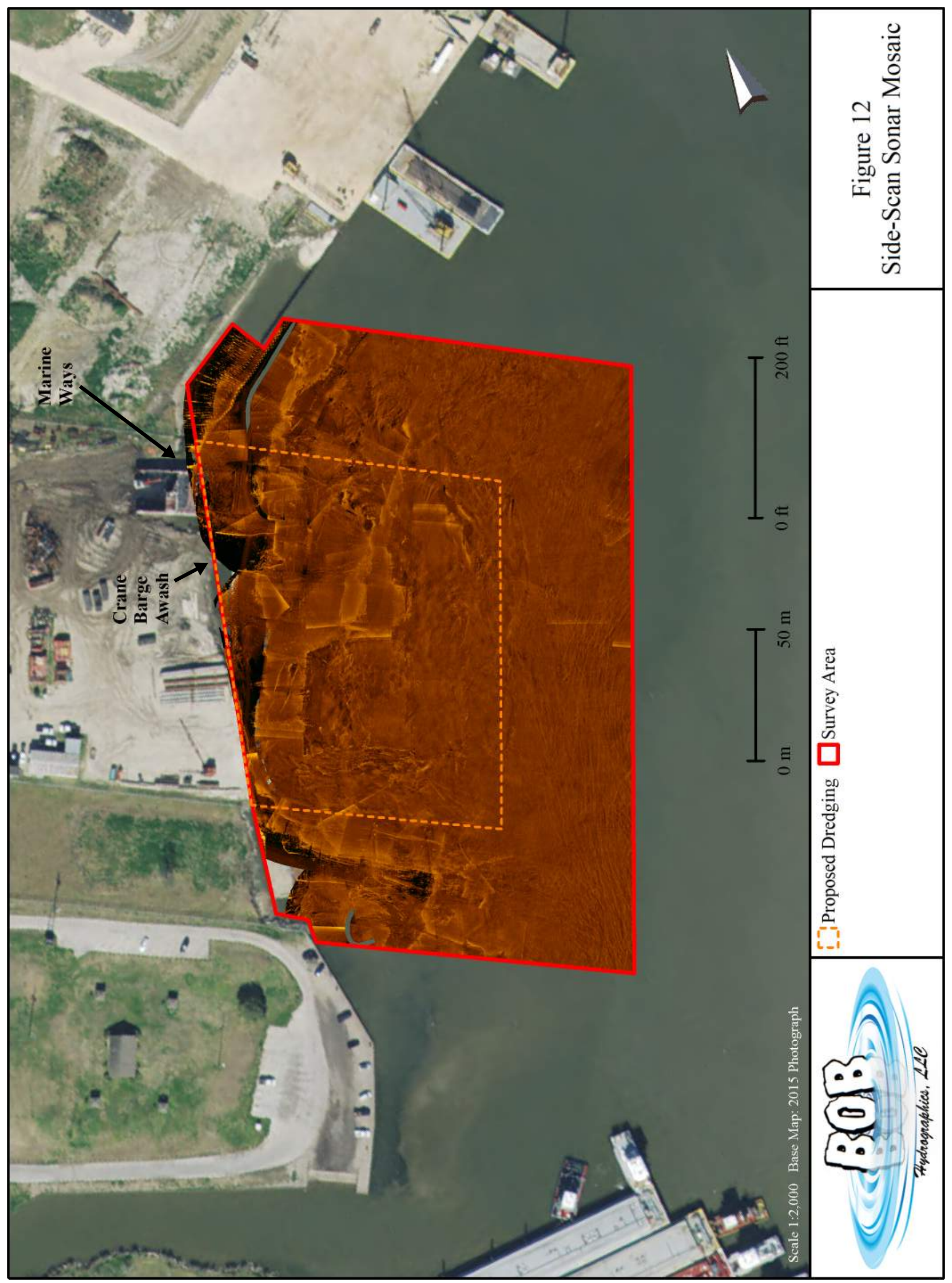


for dredging by the project sponsor to provide survey access; however, barges fronting neighboring property could not be moved. Fortunately, the side-scan sonar was able to acquire imagery of the bottom beneath parked barges. The data shows abundant linear sonar features attributed to tug boat propeller wash and to barges and spuds dragging along the bottom. No potential shipwrecks or other significant targets were discovered by the sonar survey.

\section{Recommendations}

Magnetometer data was affected, unavoidably, by nearby barges and other visible magnetic sources. The presence of buried anomaly sources cannot be ruled out, so recommendations are based on side-scan sonar data. No geophysical targets are recommended for avoidance and none are believed to meet criteria for State Antiquities Landmark or NRHP eligibility. BOB recommends cultural resource clearance for all portions of the area proposed for dredging. Avoidance buffers are mandated by The Texas Administrative Code, Title 13, Part 2, Chapter 26. The buffer for inshore waters is set at $50 \mathrm{~m}$ (164 ft) beyond significant target boundaries and around the perimeter of project-related seafloor disturbances. Disturbance of the seafloor must be avoided within this mandated buffer width around the proposed dredging area. If shipwreck remains, or other potentially historic materials, are discovered anywhere in the survey area during construction, work should be halted within $50 \mathrm{~m}(164 \mathrm{ft})$ of the find until the THC can provide guidance concerning the discovery. 


\section{References Cited}

Alperin, Lynn. 1977. Custodians of the Coast: History of the United States Army Engineers at Galveston. Galveston District, U.S. Army Corps of Engineers.

Borgens, Amy. 2004. Analysis of the Pass Cavallo Wreck Assemblage, Matagorda Bay, Texas. Master's thesis, Texas A\&M University, College Station.

Cabeza de Vaca, Álvar Núñez. 2013. Chronicle of the Narváez Expedition, Translation of 'La Relacion', translated by David Frye, edited by Ilan Stavans. Norton Critical Edition.

Chipman, Donald E., and Harriett Denise Joseph. 2010. Spanish Texas 1519-1821, Revised Edition. University of Texas Press, Austin.

Corps of Engineers. 1905. Galveston Bay, Texas. Surveys of the Engineer Department. Surveyed and drawn under the direction of Captain C.S. Riche and Captain Edgar Jadwin. Image courtesy of the Texas General Land Office.

Cotham, Edward T. Jr. 1998. Battle on the Bay: The Civil War Struggle for Galveston. University of Texas Press, Austin.

Davis, William C. 2005. The Pirates Lafitte: The Treacherous World of the Corsairs of the Gulf. Harcourt, Inc. Austin, Texas.

Estep, Raymond. 2010. Lorenzo de Zavala, In Handbook of Texas Online, accessed June 16, 2019, http://www.tshaonline.org/handbook/online/articles/fza05.

Folmer, Henri. 1940. De Bellisle on the Texas Coast, Southwestern Historical Quarterly 44 (2), October 1940.

Ford, B., A. Borgens, W. Bryant, D. Marshall, P. Hitchcock, C. Arias and D. Hamilton. 2008. Archaeological excavation of the Mardi Gras Shipwreck (16GM01), Gulf of Mexico Continental Slope. OCS Report MMS 2008-037. U.S. Department of Interior, Minerals Management Service, Gulf of Mexico OCS Region, New Orleans.

Foster, Eugene R., John Gilvar, and Steven D. Hoyt. 1993. Archival Research, Houston-Galveston Navigation Channels, Texas Project, Galveston, Harris, Liberty and Chambers Counties, Texas. Prepared for the U.S. Army Corps of Engineers, Galveston District. Document No. 920918. EH\&A, Austin, Texas.

Foster, Eugene, Ty Summerville, and Thomas Brown. 2006. The Texas Historic Overlay: A Geographic Information System of Historic Map Images for Planning Transportation Projects in Texas. PBS\&J Document 060206. Texas Department of Transportation, Environmental Affairs Division, Austin.

Foster, Eugene, Robert Gearhart, Nesta Anderson, Brandy Harris, and John Fulmer. 2007. Cultural Resources Investigations for the Port of Houston Authority's Beltway 8 Dredged Material Placement Area, San Jacinto Ordnance Depot (41HR424), Harris County, Texas. PBS\&J Austin, Texas. Prepared for the Port of Houston Authority. Texas Antiquities Permit 4142. 
Francaviglia, Richard V. 1998. From Sail to Steam: Four Centuries of Texas Maritime History, 1500-1900. University of Texas Press, Austin.

Gabrysch, R.K. and C.W. Bonnet. 1977. Land-Surface Subsidence in the Houston-Galveston Region, Texas. Prepared by the U.S. Geological Survey under cooperative agreement with the Texas Water Development Board and the cities of Houston and Galveston. Texas Water Development Board, Austin.

Garrison, E. G., C. P. Giammona, F. J. Kelly, A. R. Tripp and G. A. Wolff. 1989. Historic shipwrecks and magnetic anomalies of the northern Gulf of Mexico: Reevaluation of archaeological resource management zone 1. Volume II: technical narrative. OCS Study, MMS 89-0024. U.S. Department of the Interior, Minerals Management Service, Gulf of Mexico OCS Region.

Gearhart, Robert. 2011a. Wooden Shipwrecks of the Central and Western Gulf of Mexico. Paper presented at Offshore Technology Conference, Houston, Texas.

Gearhart, Robert. 2011b. Archaeological Interpretation of Marine Magnetic Data, Chapter 4 in The Oxford Handbook of Maritime Archaeology, Alexis Catsambis, Ben Ford, and Donny L. Hamilton, editors, pp. 90113. Oxford University Press, New York, New York.

Gearhart, Robert, John Neville, and Steven Hoyt. 1990. California, Oregon, and Washington Archaeological Resource Study, Volume IV: History. Prepared for Minerals Management Services, Pacific Region. OCS Study MMS 90-0090. EH\&A, Austin, Texas.

Gearhart II, Robert. 2016. Marine Archaeological Survey of Proposed North Jetty Sand Search, Galveston County, Texas. Prepared for HDR Engineering, Inc. Surveying And Mapping, LLC, Austin, Texas.

Hamilton, Donny. 2010. Methods of Conserving Archaeological Material from Underwater Sites, Revision No. 2. Conservation Files: ANTH 605, Conservation of Cultural Resources I. Nautical Archaeology Program, Texas A\&M University, World Wide Web, http://nautarch.tamu.edu/CRL/conservationmanual/, last accessed on 17 June 2019.

Hedrick, Layne, Martin Heaney, and Davis Graves. 2014. Maritime Archaeological Survey of the Seaway Loop Project in Crystal Bay and Scott Bay Located in Harris County, Texas. Bio-West Coastal Division, Rosenberg, Texas

Hoyt, Steven D. 1992. Underwater Investigations, Houston-Galveston Navigation Channels, Texas Project, Galveston, Harris, Liberty and Chambers Counties, Texas. Prepared for the U.S. Army Corps of Engineers, Galveston District. Document No. 920111. EH\&A, Austin, Texas.

Hoyt, Steven D., and James S. Schmidt. 1993. Bay Ground Truthing: Houston-Galveston Navigation Channels Texas Project Galveston, Harris, Liberty and Chambers Counties, Texas. Prepared for the U.S. Army Corps of Engineers, Galveston District, Galveston, Texas, by EH\&A, Austin, Texas. 
Hoyt Steven D., James S. Schmidt, and Robert Gearhart. 1995. Beneficial Use Areas Survey, HoustonGalveston Navigation Channels, Texas Project, Galveston, Harris, Liberty and Chambers Counties, Texas, Galveston Bay. Prepared for the U.S. Army Corps of Engineers, Galveston District, Galveston, Texas by EH\&A, Austin, Texas.

Hoyt, Steven D., Eugene R. Foster, and James S. Schmidt. 1998. Intensive Archival Research, Close-Order Magnetometer Survey, Dating, and Offshore Diving, Houston-Galveston Navigation Channels, Texas Project, Galveston, Harris, Liberty, and Chambers Counties, Texas Offshore, Galveston Bay, and Houston Ship Channel. Prepared for Department of the Army, Galveston District, Corps of Engineers. Document No. 970571. EH\&A, Austin, Texas.

James, Stephen R., and Michael C. Murray. 2009. Submerged Cultural Resources Remote Sensing Survey of the Proposed Ship Dock \#4, Houston Ship Channel, Harris County, Texas. Prepared for the Houston Fuel Oil Terminal Company by Panamerican Consultants, Inc., Memphis, Tennessee.

Linden, Sarah and Charles Pearson. 2014. Phase I Marine Cultural Resources Remote-Sensing Survey in Buffalo Bayou for the Proposed Kinder Morgan Export Terminal, Pasadena, Harris County, Texas. Coastal Environments, Inc. Corpus Christi, Texas.

Pearson, Charles E. and Michael Faught. 2006.Marine Remote Sensing survey for a Proposed Dolphin Fender System at the IH-10 Bridge at the San Jacinto River in Harris County, Texas. Coastal Environmental, Inc. Baton Rouge, LA

Texas General Land Office. 1847. Map of Harris District, 1847. University of North Texas Libraries, The Portal to Texas History, https://texashistory.unt.edu/ark:/67531/metapth88301/, last accessed June 16, 2019.

Tubby, Raymond. 2010. Sneed Shipbuilding Remote-Sensing Survey Project Harris County, Texas. Document No. 100047, Atkins North American, Inc., Austin, Texas.

Tubby, Ray. 2013. A Marine Archeological Remote-Sensing Survey for the Vopak Terminal Deer Park West Project, Harris County, Texas. Texas Antiquities Permit 6495. Atkins North America, Inc., Austin.

United States Coast Survey. 1852. Preliminary Sketch of Galveston Bay, Texas. A.D. Bache, Superintendent. Copy viewed on January 31, 2015 at http://www.alte-landkarten.de/images/22494-01.jpg.

United States Department of the Treasury. 1906-1946. Annual List of Merchant Vessels of the United States. U.S. Government Printing Office, Washington, D.C.

United States Geological Survey. 1955. Highlands, Tex. 7.5-minute series topographic quadrangle.

United States Geological Survey. 1967. Highlands, Tex. 7.5-minute series topographic quadrangle.

Wagner, Janet K. 2011. Harris County Transportation, The Lynchburg Ferry, Harris County Historical Commission, accessed June 17, 2019, https://historicalcommission.harriscountytx.gov/Pages/Lynchburg Ferry.aspx 
Weddle, Robert S. 1991. The French Thorn: Rival Explorers in the Spanish Sea, 1682-1762. Texas A\&M University Press, College Station, Texas.

Works Progress Administration. 1941. Ship Registers and Enrollments of New Orleans, Louisiana, Volume I (1804-1820). Prepared by the Survey of Federal Archives in Louisiana, Division of Community Service Programs. T.S. Hill Memorial Library, Louisiana State University, Baton Rouge. 
Appendix A: Texas Antiquities Permit 8878 and THC Concurrence Letter

A-1 | P a g e 


\section{TEXAS HISTORICAL COMMISSION \\ real places telling real stories}

Tuesday, June 25, 2019

Robert Gearhart

BOB Hydrographics, LLC

1315 Fall Creek Loop

Cedar Park, TX 78613-5820

Re: $\quad$ Project review under the Antiquities Code of Texas

Final Report: 16628 Market Street Dredging

Texas Antiquities Permit \# 8878

Dear Colleague:

Thank you for your Antiquities Permit Application for the above referenced project. This letter presents the final copy of the permit from the Executive Director of the Texas Historical Commission (THC), the state agency responsible for administering the Antiquities Code of

Texas.

Please keep this copy for your records. The Antiquities Permit investigations requires the production and submittal of one printed copy of the final report, a completed abstract form submitted via our online system, two copies of the tagged PDF final report on CD (one with site location information \& one without), and verification that any artifacts recovered and records produced during the investigations are curated at the repository listed in the permit. The abstract form maybe submitted via the THC website (www.thc.state.tx.us) or use url:

http://xapps.thc.state.tx.us/Abstract/login.aspx

Additionally, you must send the THC shapefiles showing the boundaries of the project area and the areas actually surveyed via email to archeological_projects@thc.texas.gov.

If you have any questions concerning this permit or if we can be of further assistance, please contact the reviewer, Amy Borgens at (512) 463-9505.

Sincerely,

Nick Barrett:

Antiquities Permit Coordinator

(512) 463-1858

Enclosures

Cc :Port of Houston Authority

16628 Market Street, LLC

\section{A-2 | Page}

GREG ABBOTT, GOVERNOR • JOHN L. NAU, III, CHAIR • MARK WOLFE, EXECUTIVE DIRECTOR 


\title{
State of Texas \\ TEXAS ANTIQUITIES COMMITTEE
}

\author{
ARCHEOLOGY PERMIT 8878
}

This permit is issued by the Texas Historical Commission, hereafter referred to as the Commission, represented herein by and through its duly authorized and empowered representatives. The

Commission, under authority of the Texas Natural Resources Code, Title 9, Chapter 191, and subject to the conditions hereinafter set forth, grants this permit for:

\section{Underwater Survey}

To be performed on a potential or designated landmark or other public land known as:

Title: 16628 Market Street Dredging

County: Harris

Location: Western bank of Old River; 300-1100 feet upstream of River Terrace Park bout ramp.

Owned or Controlled by: (hereafter known as the Permittee):

Port of Houston Authority

111 East Loop North

Houston TX 77029

Sponsored by (hereafter known as the Sponsor

16628 Market Street, LLC

16628 Market Street

Channe/view TX 77530

The Principal Investigator/Investigation Firm representing the Owner or Sponsor is:

\section{Robert Gearhart}

BOB Hydrographics, LLC

1315 Fall Creek Loop

Cedar Park, TX 78613-5820

This permit is to be in effect for a period of:

1 Years and 0 Months

and Will Expire on:

\section{$04 / 16 / 2020$}

During the preservation, analysis, and preparation of a final report or until further notice by the Commission, artifacts, field notes, and other data gathered during the investigation will be kept temporarily at:

BOB Hydrographics, LLC

Upon completion of the final permit report, the same artifacts, field notes, and other data will be placed in a permanent curatorial repository at:

Center for Archaeological Studies

Scope of Work under this permit shall consist of:

Underwater Survey, see attached scope for detail. 


\section{This permit is granted on the following terms and conditions:}

1) This project must be carried out in such a manner that the maximum amount of historic, scientific, archeological, and educational information will be recovered and preserved and must include the scientific, techniques for recovery, recording, preservation and analysis commonly used in archeological investigations. All survey level investigations must follow the state survey standards and the THC survey requirements established with the projects sponsor(s).

2) The Principal Investigator/Investigation Firm, serving for the Owner/Permittee and/or the Project Sponsor, is responsible for insuring that specimens, samples, artifacts, materials and records that are collected as a result of this permit are appropriately cleaned, and cataloged for curation. These tasks will be accomplished at no charge to the Commission, and all specimens, artifacts, materials, samples, and original field notes, maps, drawings, and photographs resulting from the investigations remain the property of the State of Texas, or its political subdivision, and must be curated at a certified repository. Verification of curation by the repository is also required, and duplicate copies of any requested records shall be furmished to the Commission before any permit will be considered complete.

3) The Principal Investigator/Investigation Firm serving for the Owner/Permittee, and/or the Project Sponsor is responsible for the publication of results of the investigations in a thorough technical report containing relevant descriptions, maps, documents, drawings, and photographs. A draft copy of the report must be submitted to the Commission for review and approval. Any changes to the draft report requested by the Commission must be made or addressed in the report, or under separate written response to the Commission. Once a draft has been approved by the Commission, one (1) printed, unbound copy of the final report containing at least one map with the plotted location of any and all sites recorded and two copies of the report in tagged PDF format on an archival quality CD or DVD shall be furnished to the commission. One copy must include the plotted location of any and all sites recorded and the other should not include the site location data. A paper copy and an electronic copy of the completed Abstracts in Texas Contract Archeology Summary Form must also be submitted with the final report to the Commission. (Printed copies of forms are available from the Commission or also online at www.thc. state.tx.us.) 4) If the Owner/Permittee, Project Sponsor or Principal Investigator/Investigation Firm fails to comply with any of the Commission's Rules of Practice and Procedure or with any of the specific terms of this permit, or fails to properly conduct or complete this project within the allotted time, the permit will fall into default status. A notification of Default status shall be sent to the Principal Investigator/Investigation Firm, and the Principal Investigator will not be eligible to be issued any new permits until such time that the conditions of this permit are complete or, if applicable, extended.

5) The Owner/Permittee, Project Sponsor, and Principal Investigator/Investigation Firm, in the conduct of the activities hereby authorizes, must comply with all laws, ordinances and regulations of the State of Texas and of its political subdivisions including, but not limited to, the Antiquities Code of Texas; they must conduct the investigation in such a manner as to afford protection to the rights of any and all lessees or easement holders or other persons having an interest in the property and they must retum the property to its original condition insofar as possible, to leave it in a state which will not create hazard to life nor contribute to the deterioration of the site or adjacent lands by natural forces.

6) Any duly authorized and empowered representative of the Commission may, at any time, visit the site to inspect the fieldwork as well as the field records, materials, and specimens being recovered.

7) For reasons of site security associated with historical resources, the Project Sponsor (if not the Owner/Permittee), Principal Investigator, Owner, and Investigation Firm shall not issue any press releases, or divulge to the news media, either directly or indirectly, information regarding the specific location of, or other information that might endanger those resources, or their associated artifacts without first consulting with the Commission, and the State agency or political subdivision of the State that owns or controls the land where the resource has been discovered.

8) This permit may not be assigned by the Principal Investigator/Investigation Firm, Owner/Permittee, or Project Sponsor in whole, or in part to any other individual, organization, or corporation not specifically mentioned in this permit without the written consent of the Commission. 9) Hold Harmless: The Owner/Permittee hereby expressly releases the State and agrees that Owner/Permittee will hold harmless, indemnify, and defend (including reasonable attomey's fees and cost of litigation) the State, its officers, agents, and employees in their official and/or individual capacities from every liability, loss, or claim for damages to persons or property, direct or indirect of whatsoever nature arising out of, or in any way connected with, any of the activities covered under this permit. The provisions of this paragraph are solely for the benefit of the State and the Texas Historical Commission and are not intended to create or grant any rights, contractual or otherwise, to any other person or entity.

10) Addendum: The Owner/Permittee, Project Sponsor and Principal Investigator/Investigation Firm must abide by any addenda hereto attached.

Upon a finding that it is in the best interest of the State, this permit is issued on 04/16/2019.
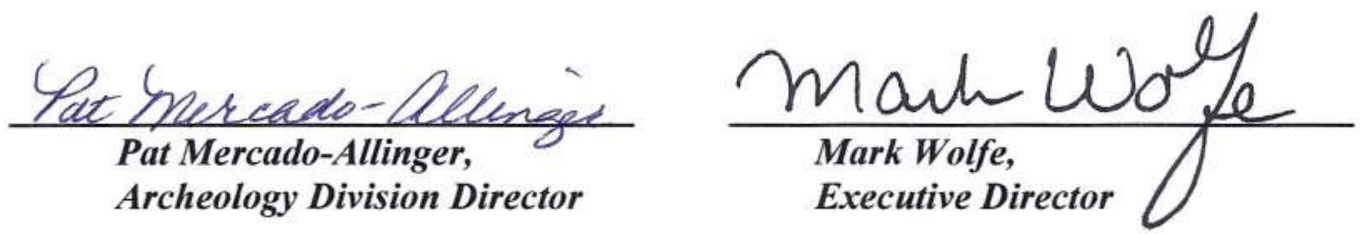


\section{TEXAS HISTORICAL COMMISSION \\ real places telling real stories}

July 12, 2019

Robert Gearhart

BOB Hydrographics, LLC

1315 Fall Creek Loop

Cedar Park, Texas 78613

Re: Project review under Section 106 of the National Historic Preservation Act of 1966 and the Antiquities Code of Texas

Draft Report Review Underwater Archeological Survey of 16628 Market Street Dredging, Harris County, Texas Texas Antiquities Permit No. 8878, Tracking No. 201909991

Dear Mr. Gearhart:

This letter serves as comment on the proposed federal undertaking from the State Historic Preservation Officer, the Executive Director of the Texas Historical Commission (THC). As the state agency responsible for administering the Antiquities Code of Texas, these comments also provide recommendations on compliance with state antiquities laws and regulations.

The review staff, led by State Marine Archeologist Amy A. Borgens, has completed its review. Bob Hydrographic, conducted an underwater archeological survey for 16628 Market Street, LLC for a proposed dredging project in Old River in Channelview, Texas. The THC concurs with the report recommendation that the remote-sensing investigation did not conclusively identify submerged cultural resources. Work may proceed as planned.

Please include the following revisions in the final report upon its submission. More information is needed to describe the undertaking - please add the purpose of the dredging (for mooring facilities, etc.,?) and the parameters of the dredging project. Enlarge Figures 11 and 12 so that they are at least page-sized (landscape view, perhaps). The planned survey lines are not legible in Figure 11. Please make sure these are discernible in the enlarged Figure 11 or add an additional separate figure that illustrates both the planned and actual transects. In the recommendations, please include a sentence that explains that the magnetometer data is inclusive and therefore the survey itself does not negate the existence of buried cultural resources. This type of explanation is typically included for surveys wherein the density of data may mask potential sites.

Thank you for your cooperation in this federal and state review process, and for your efforts to preserve the irreplaceable heritage of Texas. If you have any questions concerning our review or if we can be of further assistance, please contact Amy Borgens at amy.borgens@thc.texas.gov or 512-463-9505.

Sincerely,

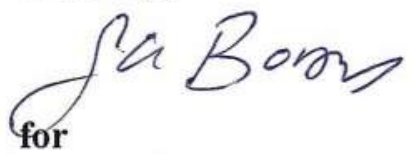

Mark Wolfe

State Historic Preservation Officer

MW/ab

A-5 | Page

GREG ABBOTT, GOVERNOR • JOHN L. NAU, III, CHAIR • MARK WOLFE, EXECUTIVE DIRECTOR

P.O. BOX $12276 \bullet$ AUSTIN, TEXAS $\bullet 78711-2276 \bullet P \quad 512.463 .6100 \bullet F 512.475 .4872 \bullet$ thc.texas.gov 